\title{
Manifestações simbólicas em Santa Elina, Mato Grosso, Brasil: representações rupestres, objetos e adornos desde o Pleistoceno ao Holoceno recente
}

\author{
Symbolic expressions in the Santa Elina shelter, Mato Grosso, Brazil: rock art images, \\ artifacts, and adornments from the Pleistocene to the late Holocene
}

\author{
Agueda Vilhena Vialou' (1) | Denis Vialou' (D) \\ 'Museum National d'Histoire Naturelle. Paris, France
}

\begin{abstract}
Resumo: Santa Elina, na Serra das Araras, no Mato Grosso, oferece uma notável composição de dois conjuntos arqueológicos excepcionais: a) um dispositivo parietal de um milhar de pinturas, adaptando-se estreitamente à morfologia do abrigo que se encontra ao pé de uma falésia calcária; b) um conjunto de ocupações distribuídas em duas sequências estratigráficas, uma indo até o Pleistoceno há 27.000 anos, a outra constituída de uma densa sucessão de ocupações durante o Holoceno, datadas entre 11.000 e 2.000 anos. Os primeiros habitantes do sítio conviveram com e caçaram uma espécie de megafauna, tornada fóssil no início do Holoceno: o Glossotherium lettsomi. Três adornos feitos nos ossículos do animal são provas de sua importância para os caçadores. A utilização intensiva pelos habitantes de pigmentos minerais, principalmente vermelhos (hematitas) e a de vegetais (madeira, fibras e folhas), caracteriza as ocupações que se seguem: particularmente, 'pavimentações' feitas de blocos manchados de vermelho, ou ornamentos corporais trançados. Os conjuntos líticos, principalmente feitos de calcário local, duro e fácil de lascar, são bem presentes em todas as ocupações. Os utensílios com reentrância dominam durante o Pleistoceno. É um dos mais antigos sítios da América do Sul, mostrando a intensidade de povoamentos pré-históricos no centro do continente.
\end{abstract}

Palavras-chave: Dispositivo parietal. Pinturas. Ornamentos. Pigmentos. Megafauna.

Abstract: The Santa Elina site, located in the Serra das Araras (Mato Grosso), offers a remarkable conjunction of two extraordinary archaeological complexes: a series of wall paintings (approximately 1,000) closely fitted to the morphology of the shelter, at the bottom of a tall limestone cliff, as well as a series of occupations in two stratified sequences, one dating back to the Pleistocene (27,000 years ago), and the other a dense group of occupations during the Holocene (dated between 11,000 and 2,000 years ago). The first inhabitants of the site lived alongside and hunted the megafauna species Glossotherium lettsomi, which become a fossil in the early Holocene; three ornaments made from small bones of this animal show its importance. The inhabitants intensively utilized pigments from minerals (mainly red, from hematite) as well as plants (wood, fibers, and leaves), particularly in "paved flooring" made of red-stamped blocks or braided body adornments. The lithic assemblages, which mainly were made of the local hard and easily chipped limestone, are present in large numbers in the occupations, while notched tools predominated during the Pleistocene. Santa Elina is one of South America's oldest sites, and demonstrates the intensity of prehistoric settlements in the center of this continent.

Keywords: Wall construction. Paintings. Adornments. Pigments. Megafauna.

VILHENA VIALOU, Agueda; VIALOU, Denis. Manifestações simbólicas em Santa Elina, Mato Grosso, Brasil: representações rupestres, objetos e adornos desde o Pleistoceno ao Holoceno recente. Boletim do Museu Paraense Emílio Goeldi. Ciências Humanas, Belém, v. 14, n. 2, p. 343-365, maio-ago. 2019. DOI: http://dx.doi.org/10.1590/1981.81222019000200006.

Autora para correspondência: Agueda Vilhena Vialou. Museum National d'Histoire Naturelle. Jardin des plantes 57, rue Cuvier, Paris 75005, France (avialou@gmail.com).

Recebido em 22/11/2018

Aprovado em 31/01/2019
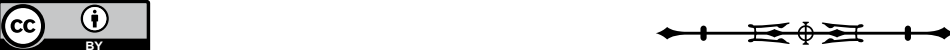


\section{SANTA ELINA: ATIVIDADES DOMÉSTICAS E COMPORTAMENTOS SIMBÓLICOS}

O abrigo de Santa Elina (Jangada, Mato Grosso) conservou dois conjuntos arqueológicos notáveis: uma sucessão de ocupações sobre aproximadamente $80 \mathrm{~m}^{2}$, com até 350 $\mathrm{cm}$ de profundidade no centro do abrigo, e um dispositivo parietal de $60 \mathrm{~m}$ de comprimento. Os comportamentos simbólicos demonstrados por cerca de mil representações pintadas e gravadas ou por dezenas de objetos, como adornos, e comportamentos técnicos e domésticos, evidenciados principalmente por milhares de artefatos e por fogueiras, estão, assim, topograficamente associados.

As pinturas feitas com óxidos minerais não permitem datações radioatômicas. Entretanto, a análise aproximada da construção do dispositivo parietal indica fases temáticas, tecnoestilisticas distintas e distribuições em parte diferenciadas no espaço parietal: esse dispositivo compreende claramente várias fases ou períodos em um tempo longo.

As numerosas datações radioatômicas, mais de cinquenta, obtidas nas diversas ocupações evidenciadas em estratigrafia e sobre toda a extensão da área escavada, abrem um leque cronológico considerável, contando duas fases bem distintas: uma ao redor de 27.000 anos antes do presente (AP); outra compreendida entre 11.000 e 2.000 anos antes do presente.

A conjunção topográfica dos dois grupos arqueológicos do sítio Santa Elina levanta a questão sobre seus encaixamentos no tempo e no espaço naturalmente circunscritos em relação ao abrigo.

\section{SANTA ELINA, ABRIGO ISOLADO}

Santa Elina (latitude sul $15^{\circ} 27^{\prime} 28^{\prime \prime} \mathrm{S}$, longitude oeste $56^{\circ} 46^{\prime}$ '93", no município de Jangada) é um abrigo rupestre e habitacional, situado quase no centro geodésico da América do Sul, a 120 km a NNE de Cuiabá, capital do estado de Mato Grosso, apresentando, juntamente a uma parede rica em representações figurativas pintadas, uma das mais longas sequências estratigráficas de sítios pré-históricos da América onde a presença humana foi claramente evidenciada a partir de 27.000 anos atrás (Vilhena Vialou, 2005; Vialou et al., 2017). Está localizado no flanco oriental de um dobramento sinclinal de calcário dolomítico pré-cambriano com os arenitos de Formação Raizama que liga a serra das Araras à serra da Água Limpa (Alvarenga, 2005; Ross, 2005). Frente ao abrigo, do outro lado do vale, a serra atinge $800 \mathrm{~m}$ de altitude. Faz parte do regime hidrográfico das fontes da bacia do rio Paraguai, em direção sul-sudoeste ao pediplano cuiabano e ao Pantanal, delimitando-se ao norte pelas fontes dos afluentes da bacia amazônica (Figura 1).

O hábitat ocupa a parte central do abrigo. Está contido entre a parede vertical ligeiramente inclinada do dobramento sul e um enorme bloco paralelepipédico, ao norte, em direção ao vale. Com seus relevos marcados e profundos, a serra das Araras forma uma paisagem original e oferece condições climáticas totalmente diferentes das que correspondem à depressão cuiabana e ao cerrado regional. Os estudos paleobotânicos e ambientais mostraram que os vales ficaram distanciados das estações

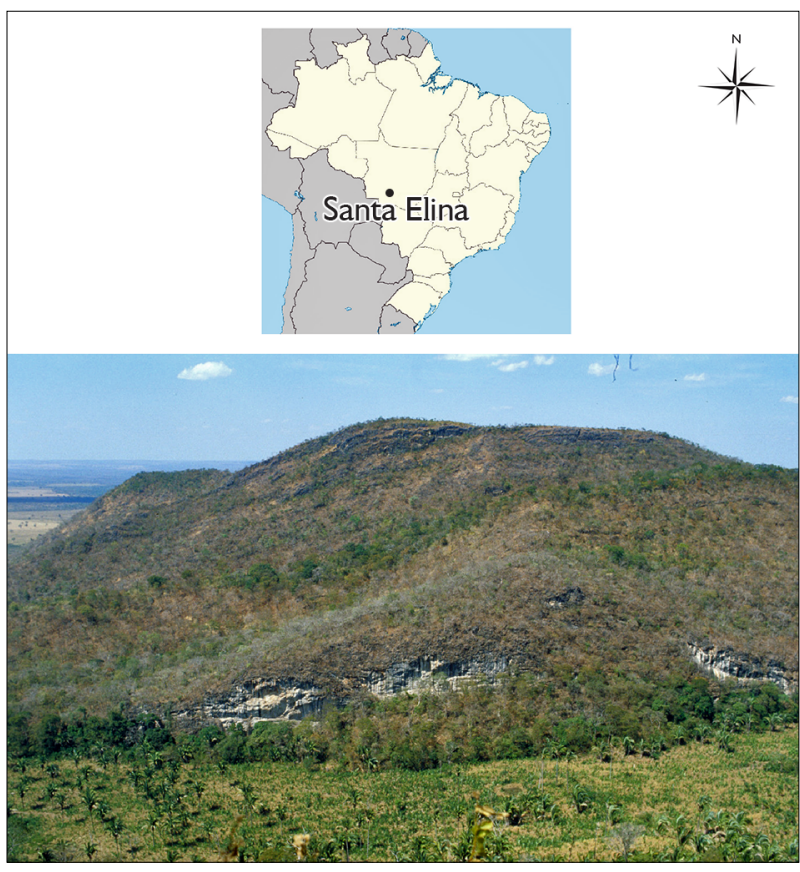

Figura 1. Afloramento calcário na serra das Araras, abrigo Santa Elina, Mato Grosso. Foto: Thierry Aubry (2001).

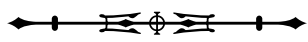


de intenso calor e da aridez (Ceccantini, 2005). A serra funcionou como um refúgio natural, favorável a espécies animais e vegetais próprias.

As prospecções feitas em um raio de 10-15 km no dobramento exterior da serra, onde se situa o abrigo, revelaram raras concentrações de cerâmica na superfície e também peças líticas, mas nenhum sítio seria comparável ao de Santa Elina. Nenhum vestígio arqueológico foi encontrado nas proximidades do abrigo. Devido aos poucos estudos feitos nos platôs da região oeste e centraloeste do Brasil, as descobertas arqueológicas do abrigo de Santa Elina continuam sendo singulares para as ocupações pleistocênicas. Os vestígios mobiliários encontram-se efetivamente concentrados nesse espaço, abrigado das intempéries, aberto entre a alta parede de calcário précambriano, onde foram executadas as representações, e um enorme rochedo, também de calcário pré-cambriano, no exterior, do lado do vale.

No entanto, dois pequenos conjuntos rupestres foram encontrados fora do abrigo: um na direção leste, a uns $30 \mathrm{~m}$, contendo dois pequenos desenhos lineares vermelhos, evocando silhuetas de animais; o outro, a 200$300 \mathrm{~m}$, na direção oeste, reúne traçados lineares vermelhos encaracolados em espiral, sobre 1,5 $\mathrm{m}^{2}$ de parede.

\section{ÁREA HABITACIONAL}

Acompanhando a parede contendo representações picturais e picoteadas, foram realizadas escavações evidenciando uma sucessão de várias ocupações em um espaço longo de $60 \mathrm{~m}$ de comprimento e relativamente exíguo, de 3 a 5 m de largura, em depósitos pleistocênicos e holocênicos formados entre duas paredes ligeiramente inclinadas $\left(70^{\circ}\right)$ (Figura 2).

Uma sondagem de $6 \mathrm{~m}^{2}$, dos metros 16 a 18 , apresentou uma sedimentação subatual muito limitada, de $60 \mathrm{~cm}$ de profundidade, atingindo a rocha, ou seja, o topo da camada sinclinal exterior. As escavações, em sequência, foram realizadas sobre $80 \mathrm{~m}^{2}$, na parte central do abrigo, dos metros 19 a 39. Em relação à superfície atual, o preenchimento dos depósitos para as mais antigas ocupações atingiu uma profundidade de $350 \mathrm{~cm}$. Uma sondagem, nos metros $21 \mathrm{~B} / \mathrm{C}$, atingiu $480 \mathrm{~cm}$, os quais, $130 \mathrm{~cm}$ mais profundos do que os outros, mostraram-se estéreis arqueologicamente.

Além de presença de raros vestígios cerâmicos na camada superficial, mostrando simples passagens pelo abrigo, e de uma espiga de milho datada de $400+/-50$ anos AP (Gif 8955), três grandes unidades estratigráficas contendo vestígios de presença humana foram estabelecidas e numeradas, da mais recente à mais antiga (Benabdelhadi, 2005; Vialou et al., 2017): a unidade I é holocênica, corresponde a uma sedimentação fina e pulverulenta, não pedogeneizada, contendo muitos vestígios vegetais: carvões, estacas de madeira, vegetais

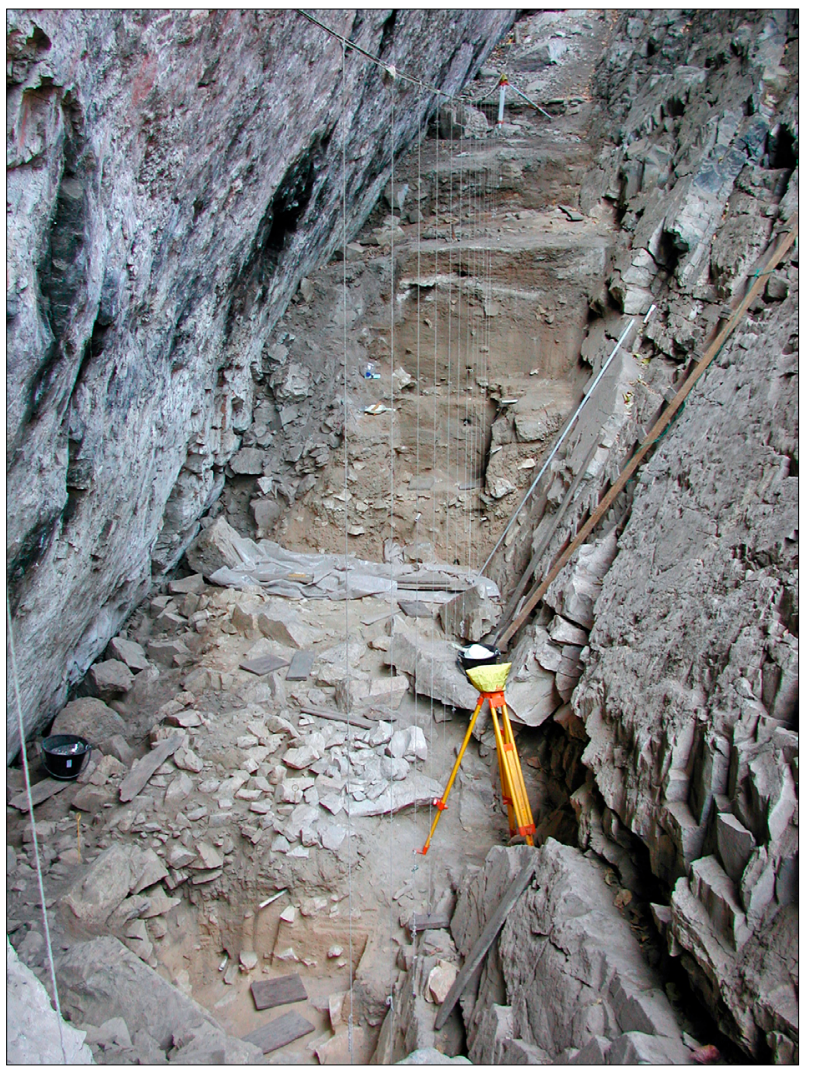

Figura 2. Abrigo Santa Elina: escavações e corte estratigráfico de 27.000 a 2.000 anos atrás. Foto: Agueda Vilhena Vialou e Denis Vialou (2003).

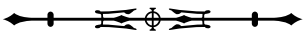


secos (frutos, palhas, folhas e folíolos de palmeiras). Estabelece-se sobre $140 \mathrm{~cm}$ de espessura. Possui uma sequência de ocupações ininterruptas de 1.800 a 7.000 anos atrás. São os vestígios antrópicos que definem essa unidade. A unidade II, a partir de $1 \mathrm{~m}$ de profundidade e caracterizada por um sedimento arenoso de $1 \mathrm{~m}$ de espessura, corresponde ao início do Holoceno e à passagem Pleistoceno-Holoceno, com ocupações indo de 7.000 a 11.000 anos atrás, havendo para a mais antiga a associação in loco com megafauna extinta, Glossotherium lettsomi (Cartelle, 2005). A unidade III, pleistocênica, com cerca de $110 \mathrm{~cm}$ de espessura a partir de $240 \mathrm{~cm}$ de profundidade e composta de sedimentos arenosos intercalados por camadas de blocos calcários, situa-se entre 17.000 e 27.000 anos atrás, com ênfase às mais antigas ocupações humanas, em associação com a megafauna extinta, Glossotherium lettsomi, a partir de $300 \mathrm{~cm}$ de profundidade (Feathers, 2005; Fontugne et al., 2005). E, enfim, uma quarta unidade, pleistocênica, não tem ocorrência de vestígios humanos e faunísticos. Conhecida por uma sondagem com até $480 \mathrm{~cm}$ de profundidade, é totalmente estéril arqueologicamente, sendo formada por estratos intercalando depósitos arenosos de camadas espessas $(30 \mathrm{~cm})$ de plaquetas calcárias desprendidas. As datações feitas por Optical Stimulated Luminescence Dating (OSL) são anteriores a 27.000 anos atrás.

Não há vestígios aparentes na superfície, provenientes do chão atual do abrigo, que sejam testemunhos de passagens bem recentes de indígenas, dos nativos no local, como os Umutina da outra encosta da serra. Os vestígios encontrados estão associados às atividades domésticas, sendo contextualizados espacialmente pelas pesquisas de campo através das escavações feitas por decapagens centimétricas do sedimento. A área habitacional foi evidenciada pelas numerosas estruturas de combustão, formadas pela disposição de blocos e de placas de calcário contendo concentrações de carvões e de cinzas, mas também de vegetais, folhas de palmeiras, gravetos e frutos e de material lítico, como as plaquetas de hematitas e os instrumentos elaborados principalmente em rocha calcária (Vilhena Vialou, 2005).

A relação do morador de Santa Elina com a flora é verificada pela presença de frutos comestíveis (ScheelYbert; Solari, 2005) e pela utilização de grande variedade de plantas, provenientes de ambientes de mata ciliar e de mata semidecídua que seguramente, pelas análises botânicas, existiam ao redor do abrigo.

É notável a importância na organização espacial da evidenciação de 84 estacas, algumas longas, com $60 \mathrm{~cm}$ de comprimento, que se conservaram fincadas e alinhadas ao longo das paredes norte e sul, distribuindo-se equitativamente de cada lado, sobre $11 \mathrm{~m}$. Elas mantêm um distanciamento quase que regular, de $2,50 \mathrm{~m}$, formando alinhamentos próximos às paredes, entre os metros $19 \mathrm{e}$ 28. Algumas estacas se posicionam no setor mais estreito, entre os metros 33 e 39 , enquanto que, dos metros 29 ao 32, existe uma espécie de obstáculo à circulação na área, formando uma espécie de um cerco com 14 estacas, talvez devido a uma declividade oeste-leste mais pronunciada a partir deste setor (Figura 3). Tais estacas correspondem, em grande parte, a madeiras de alta densidade e durabilidade, como jatobá (Hymenaea sp.), aroeira (Astronium sp.), ipê (Tabebuia sp.), mas também de bambu (Guadua sp.) - que, apesar de não tão durável, é apreciado pela retidão do caule -, entre outras plantas conhecidas e ainda utilizadas atualmente, as quais foram transformadas em estacas (Kamase, 1999; Ceccantini, 2002). As funções dessa importante estrutura ainda não ficaram bem definidas, mas poder-se-ia supor como sendo útil para a confecção de jiraus, de 'prateleiras' e, em se tratando de uma relação de face a face entre os alinhamentos citados, poderia servir até como 'abrigo', protegendo a moradia da intensidade do sol, talvez com folhas de palmeiras, tendo como seus sustentáculos essas estacas, evidenciadas pelas escavações. Note-se que foram encontradas numerosas folhas de palmeira ao longo das escavações dos níveis mais recentes.

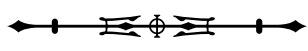




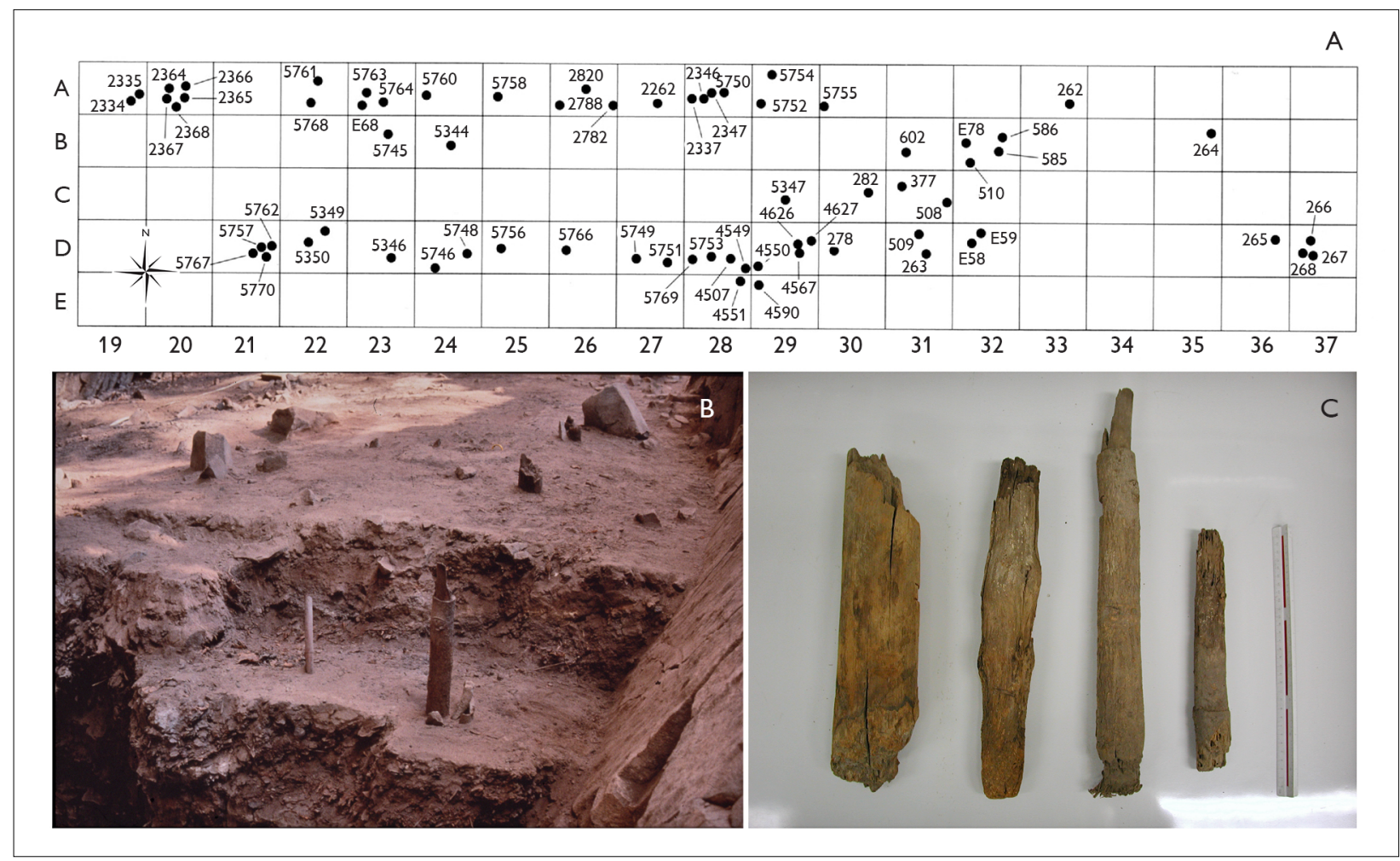

Figura 3. A) Distribuição espacial das estacas entre 4.000 e 2.000 anos atrás; B) estacas in loco durante as decapagens; C) alguns tipos de estacas. Fonte: Ceccantini (2002) (A). Fotos: Agueda Vilhena Vialou e Denis Vialou (1996) (B); Luciane Kamase (1999) (C).

\section{REPRESENTAÇÕES PARIETAIS}

\section{DISPOSITIVO PARIETAL}

O dispositivo parietal compõe-se de três partes distintas, porém adjacentes topograficamente no abrigo. A principal, composta por 843 unidades, ocorre sem nenhuma descontinuidade ao longo da parede calcária inclinada, praticamente retilínea nesse local, orientada a leste-oeste.

Nessa parede de $54 \mathrm{~m}$ de comprimento, as representações estão essencialmente localizadas na altura de uma pessoa, desde o solo atual até $2 \mathrm{~m}$ de altura. Existem, entretanto, representações situadas a mais de $3 \mathrm{~m}$ de altura e até $4 \mathrm{~m}$ na parte central do abrigo (dos metros 19-20 aos metros 30-31 - Figuras 4A e 4B. As representações mais baixas chegam até o solo atual. Não houve representações recobertas por sedimentos.
A segunda parte, composta por 88 unidades, está localizada em uma estreita cornija sub-horizontal (de no máximo $1 \mathrm{~m}$ de largura), a 12,5 m de altura na vertical da zona central do abrigo (Figura 5). $\bigcirc$ acesso à cornija se faz pela extremidade oeste do abrigo, graças a uma acumulação em declividade de blocos e rochedos caídos, tornando acessível a zona alta em relação à zona horizontal do depósito sedimentar, sobre $40 \mathrm{~m}$ desde sua extremidade oriental, onde se encontram as primeiras pinturas do conjunto principal. A primeira representação, uma mancha oval vermelha, se vê na altura do metro 64, pouco antes de se introduzir a leste na cornija, onde se destaca, de maneira espetacular, a figura de um indígena com seus notáveis ornamentos cefálicos no metro 58 (Figura 6). As últimas (dos cervídeos) encontram-se na vertical do metro 36, no local onde a cornija se torna perigosa, quase que impraticável (Figura 7).

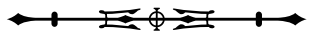




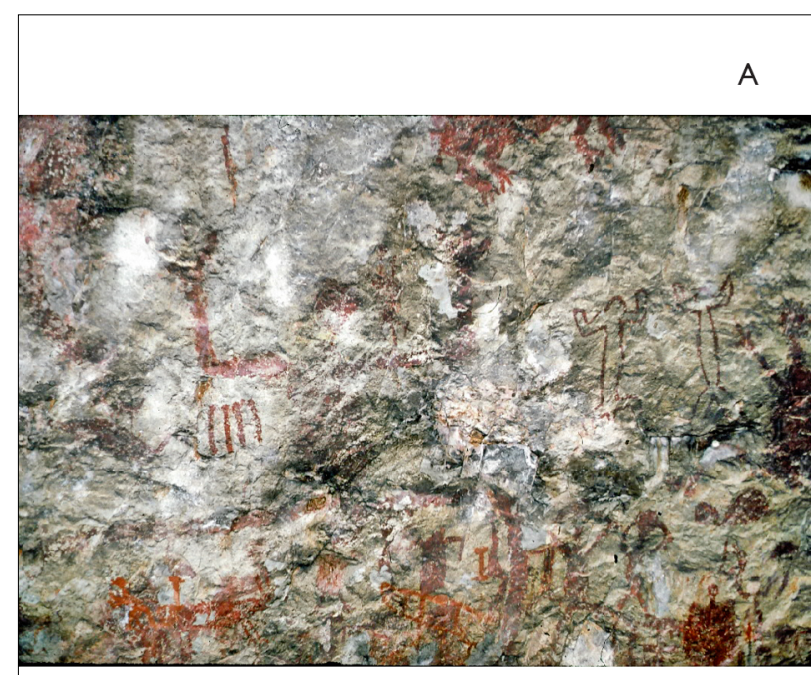

B

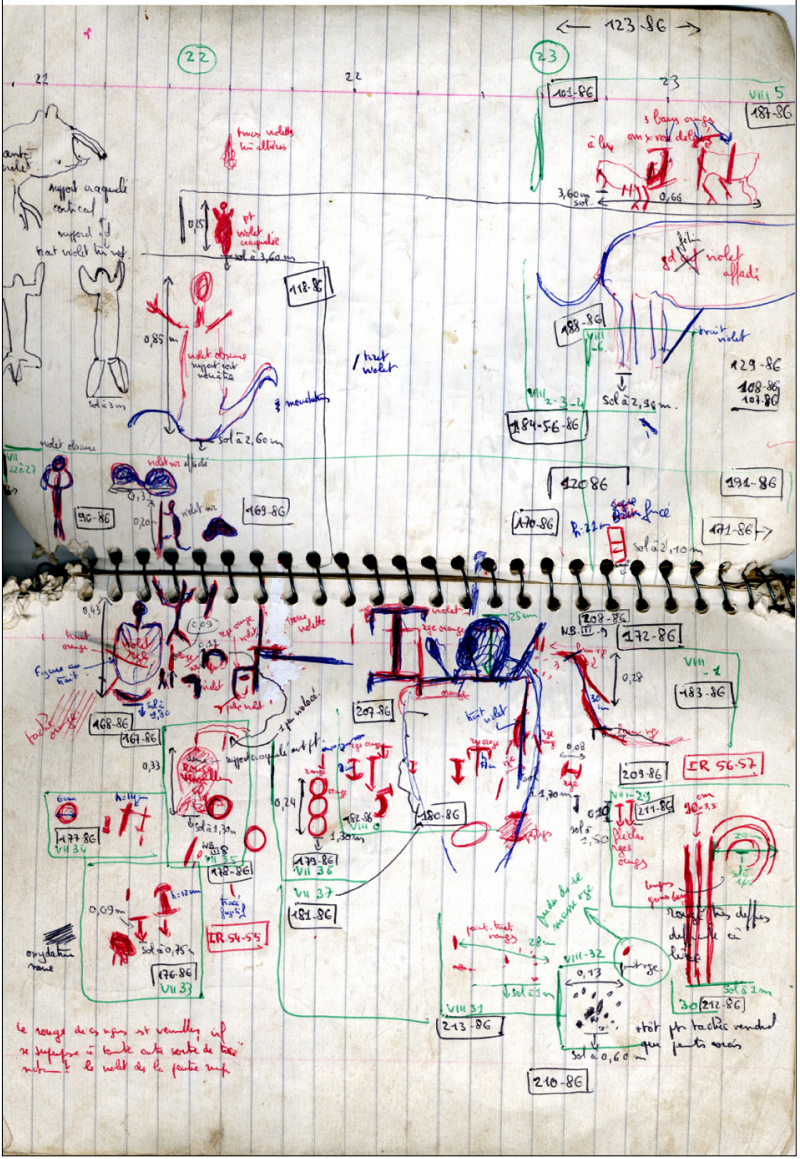

Figura 4. A) Painel central; B) pinturas e desenhos de cores vermelha, violeta, laranja e preta, acumuladas no centro do dispositivo parietal. O casal de orantes se distingue. Fotos: Denis Vialou (1987).

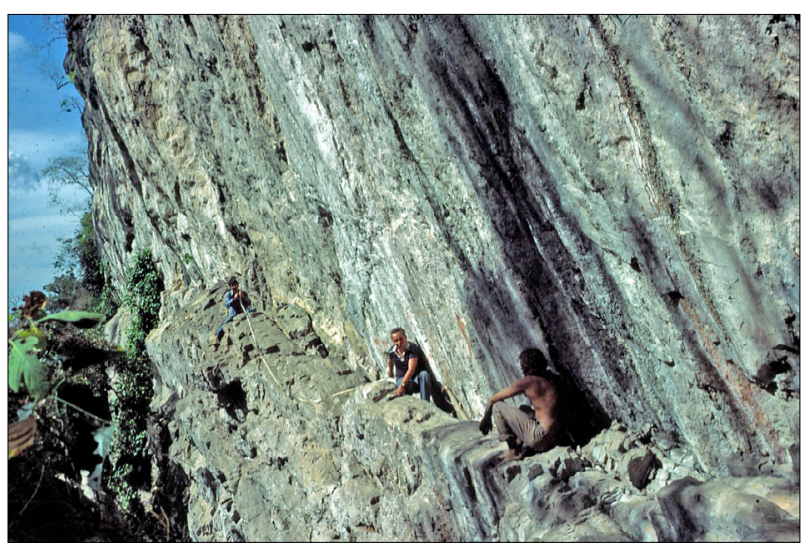

Figura 5. Vista da cornija, em cima da zona central pintada do abrigo. Foto: Agueda Vilhena Vialou e Denis Vialou (1984).

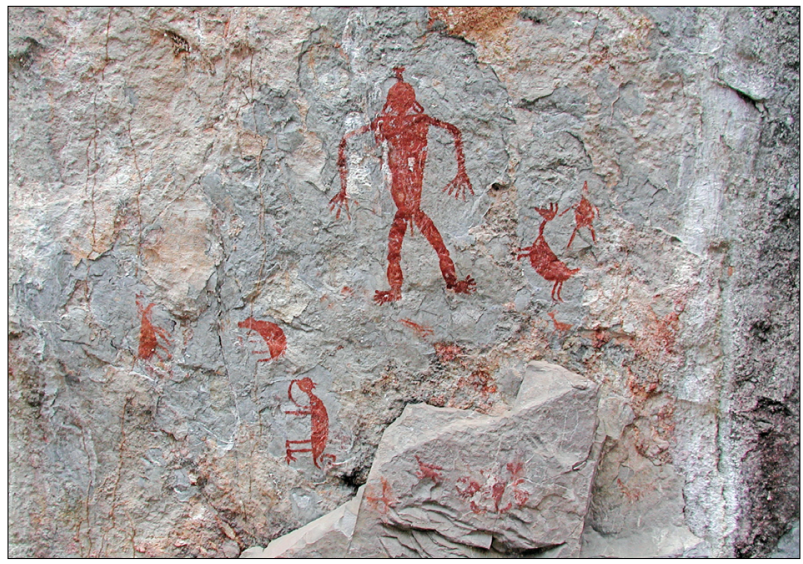

Figura 6. Pinturas no início da cornija: homem com ornamentos e animais realistas e fantásticos. Foto: Agueda Vilhena Vialou e Denis Vialou (2002).

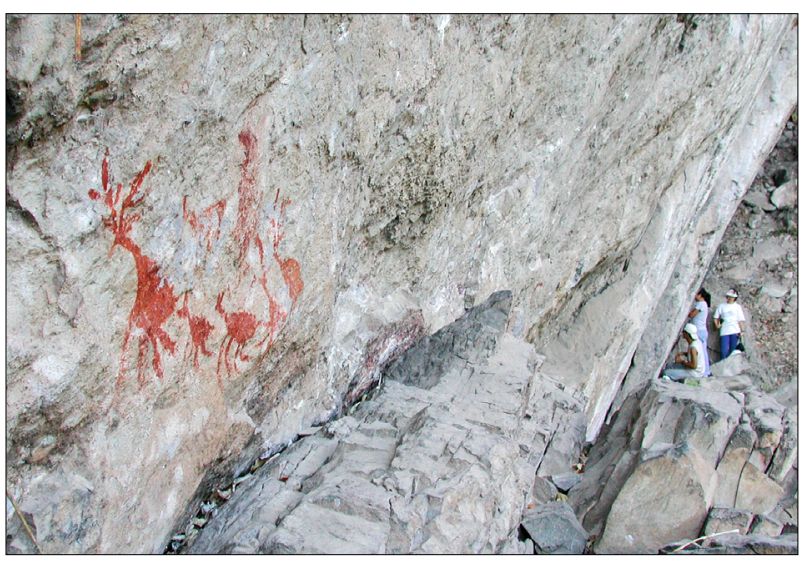

Figura 7. Pinturas de cervídeos no final leste da cornija. Foto: Agueda Vilhena Vialou e Denis Vialou (2002).

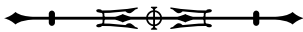


A terceira parte do dispositivo é reduzida, uma dezena de sinais lineares, sendo que dois são divididos em compartimentos, e de sinais pontuados de cor vermelha, localizados na parte superior de um enorme bloco destacado, o que forma a parede protetora do lado norte (o do vale) do abrigo, nos metros 36-37 e 45-47. Duas manchas, que podem ser resíduas da palheta, e um traço linear simples (igualmente vermelhos) foram observados nos rochedos que afloram nos metros 12-14, no alinhamento do bloco calcário, no lado norte.

O dispositivo parietal principal ocupa a totalidade da parede disponível (e acessível) do abrigo propriamente dito. No entanto, a análise das diferentes séries que o compõem mostra que suas próprias extensões não ocupam jamais a totalidade do dispositivo parietal disponível. Por outro lado, certas porções do dispositivo são mais densas e mais variadas do que outras, por exemplo nos metros 20 a 25 ou nos metros 39 a 46. Outras porções são bem pouco densas: nos cinco primeiros metros do dispositivo, nos metros 18-19, ou bem nos últimos metros. Essas disparidades espaciais, combinadas com as escolhas temáticas ou as categorias de representações, figurativas ou abstratas-geométricas, indicam que o espaço gráfico que forma a parede rochosa não foi considerado como homogêneo ou neutro: ele participou fundamentalmente da construção simbólica, feita em um ou em vários tempos (Vialou, 2005).

\section{CATEGORIAS GERAIS DAS REPRESENTAÇÕES}

Trata-se das mais frequentes categorias das representações rupestres pré-históricas no mundo, realizadas durante os últimos milênios antes do presente e também no atual, nos locais em que populações, vivendo mais conectadas com a natureza, conservaram modos ancestrais de expressão gráfica nas paredes rochosas, mas também sobre suportes orgânicos. São as representações geométricas, abstratas: de tipos correntes - designadas, então, como 'sinais' ou 'signos' - ou de tipos complexos e raros - designadas, então, como 'motivos'. O dispositivo de Santa Elina conta com 620 sinais e motivos pertencentes a cerca de quarenta tipos. Os mais numerosos e constantes em suas formulações gráficas são os tipos lineares: 226 , geralmente traços retilíneos e verticais bastante espessos, como barras, ou então finos, como traços curtos (travessão): seja com traço único ou traço duplo e, menos frequentemente, com vários traços.

A grande maioria desses sinais lineares simples (um dos mais comuns, com os pontos, nos conjuntos rupestres) está agrupada nos metros 20 a 47. Eles estão, em geral, associados a sinais pontuados (136), particularmente nos metros 27 a 38. Mas suas distribuições no dispositivo parietal ocorrem dos metros 3-5 ao metro 47.

Cento e cinquenta e um sinais lineares têm em uma ou nas duas extremidades um apêndice: seja um traço curto perpendicular seja um traçado em $\mathrm{V}$, invertido. Quando o eixo retilíneo é comprido, os sinais parecem flechas (Figura 8). Quando ele é curto e do comprimento

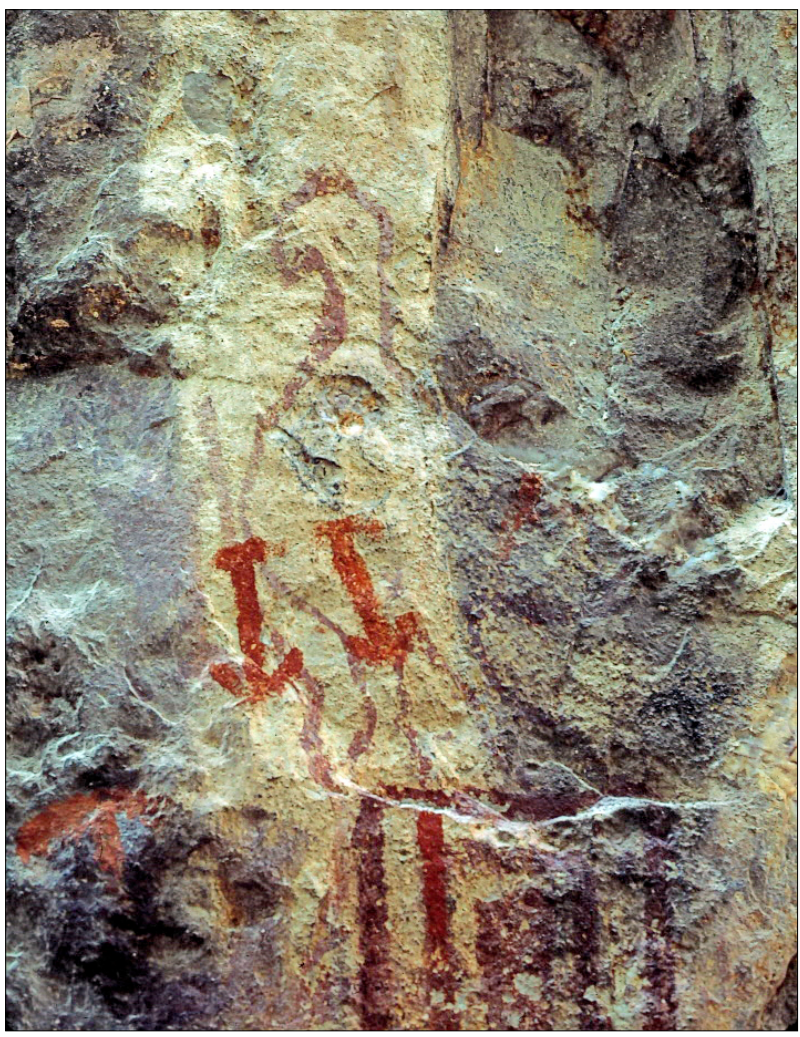

Figura 8. Flechas superpondo desenho de pássaro em tinta vermelha, com sinal linear embaixo. Foto: Agueda Vilhena Vialou e Denis Vialou (1987).

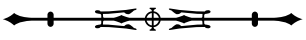


das ramificações do $V$, pode-se evocar desenhos de patas tridátilas de pássaro. Note-se que, por várias vezes, esses sinais tridátilos estão verticalmente alinhados, como se tratasse de uma pista de pegadas. Pode ser igualmente que esses sinais tridátilos, quando isolados, simulem esquematicamente o sexo feminino. Os tridátilos e essas flechas com ou sem o traço curto basal, quase todos vermelhos (senão violetas ou pretos), têm a mais ampla distribuição no dispositivo, indo do metro 5 aos metros 39-47. Outra especificidade dos sinais lineares com eixo retilíneo alongado, quase que todos em vermelho, vem de seu posicionamento frequente, por volta de $2 \mathrm{~m}$ de altura na parede. Esta série de lineares dispostos constantemente na mesma altura exprime certa homogeneidade.

Essas particularidades gráficas repetitivas e topográficas dos sinais lineares sobre a extensão máxima do dispositivo conferem-lhe certa unidade simbólica-conceptual. Os jogos de superposições e os dos encaixamentos com os outros grupos de representações (figurativas e abstratas) indicam que os sinais lineares não foram os primeiros a serem realizados na parede. Outros tipos de desenhos geométricos assimilam-se a sinais, como cruzes, ou motivos como círculos ou quadrangulares com preenchimentos lineares. Esses motivos são mais numerosos nos metros 33 a 45 e nos metros 25 a 28.

Os 620 sinais e os motivos geométricos recenseados constituem a primeira categoria no abrigo Santa Elina, à maneira do que acontece nos sítios rupestres pelo mundo, durante todo o Holoceno. Eles não oferecem particularidades gráficas nem técnicas em relação aos sinais e motivos geométricos rupestres em geral. Nesse sentido, eles diferem completamente dos conjuntos originais de motivos geométricos complexos, desenhados em cores, frequentemente vivas, da 'tradição São Francisco', presentes tanto no Nordeste como na Chapada Diamantina, na Bahia (Etchevarne, 2007), mas também no vale do Peruaçu, em Minas Gerais (Isnardis, 2009).

A proporção das representações geométricas em relação às representações figurativas no abrigo, comparável ao que ela é em geral, está invertida no dispositivo da cornija: somente 25 sinais e motivos para o total recenseado de 88 representações. A metade desses geométricos são sinais elementares: pontos, manchas e barras. Os sinais menos comuns são: um oval, duas cruzes, um quadrângulo simples, um quadrângulo com barras paralelas (Figura 9), dois traços curtos paralelos, quatro curvilíneos, sendo um deles disposto por cima de um curto eixo retilíneo. Não se distinguiram motivos geométricos complexos. As diferenças tão nítidas na composição das representações abstratas dos dois setores parietais de Santa Elina poderiam fazer pensar que eles são estranhos um ao outro, independentes. A forte similitude gráfica de algumas das representações humanas prova, no entanto, seu estreito parentesco, constitutivo da unidade de lugar, o próprio sítio.

A segunda categoria de representações no abrigo está constituída por 68 animais e 49 humanos, em um estilo figurativo, geralmente pouco elaborado e desigualmente expressivo. As representações humanas estão distribuídas em três grupos: sete são reunidas nos metros 4-7, 22 nos metros 14 a 25, mais particularmente nos metros 19 a 25, no centro do abrigo (onde a sequência de ocupações é a mais longa e a mais antiga). $\bigcirc$ terceiro agrupamento compreende 13 representações nos metros 39-43. Uma figura esquemática fica isolada no metro 56 , não longe do acesso à cornija.

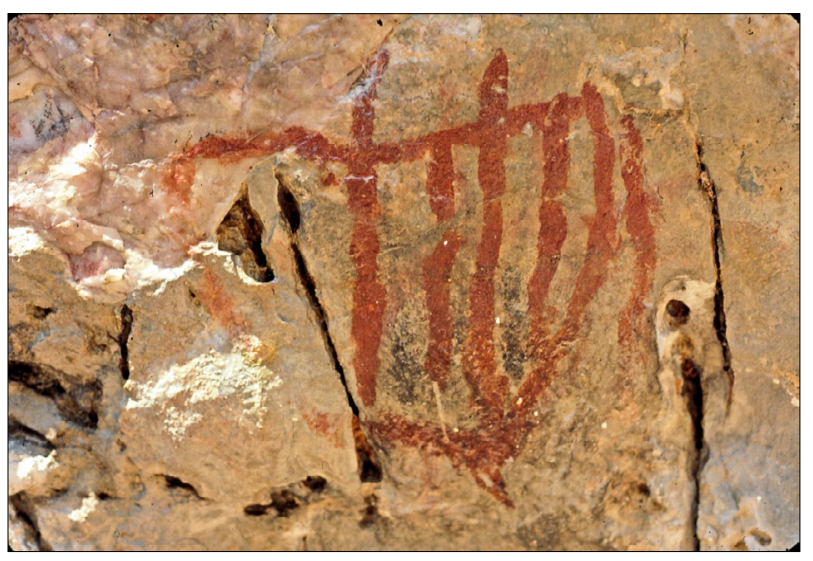

Figura 9. Sinal de tipo quadrangular com barras internas, em tinta vermelha. Foto: Agueda Vilhena Vialou e Denis Vialou (1987).

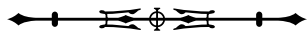


As formulações estilísticas dos humanos são tão heterogêneas que é impensável que elas tenham sido feitas por um só grupo e/ou em um único momento: existe aí uma chave para discriminar séries ou fases na construção do dispositivo. As únicas representações humanas exprimidas em opção figurativa (relativamente) realista estão agrupadas no início do dispositivo (metros 5 a 7), afastadas das outras representações humanas e animais. São cinco figurações pintadas de preto, vistas de face, entre elas uma sustentando, na extremidade do braço, uma menor, passando facilmente por uma criança (Figura 10). Os membros estão separados do corpo. Dois mostram uma ornamentação auricular. Uma sexta figuração preta é semelhante, mas apresenta uma cabeça animal (focinho, grandes orelhas). Uma figuração humana esquematizada, vermelha, encontra-se próxima (metro 4): um tipo de $\mathrm{X}$ apertado, alongado, desenha um tronco triangular e membros inferiores; está marcado por uma linha horizontal para figurar os ombros e os braços, com traços curtos terminais para as mãos (ou dedos); no centro, um apêndice tosco simula uma cabeça.

Duas representações humanas em preto-violeta dos metros 24-25 lembram esse primeiro grupo; mas sua expressão realista é nitidamente mais fraca. Nota-se, em 21-22 metros, um par de silhuetas em violeta, vistas de face, que carregam sobre suas cabeças um objeto

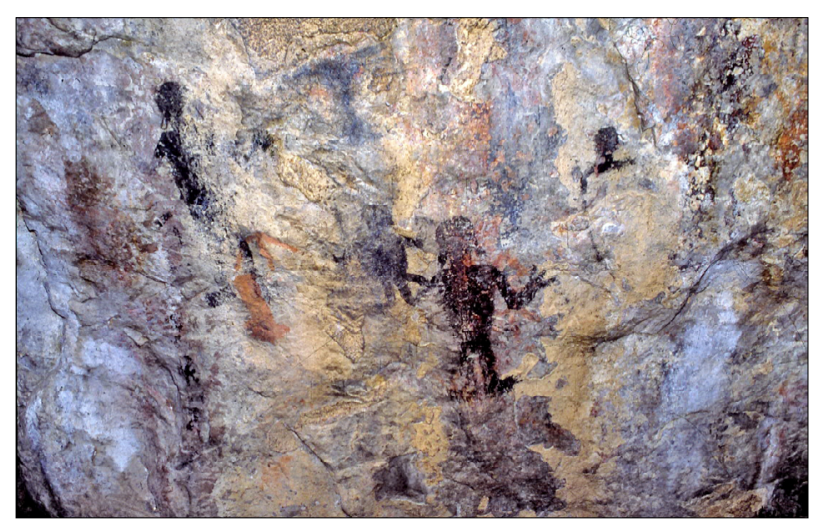

Figura 10. Grupo de figuras humanas pintadas de cor preta, na extremidade leste do dispositivo parietal. Foto: Agueda Vilhena Vialou e Denis Vialou (1987). volumoso (trouxa, cabaça ou qualquer outra coisa). Todavia, as silhuetas são bem pouco humanas. De fato, a comparação estilística claramente justa se faz com os quatro humanos pintados na cornija: vistos de face, membros afastados do corpo e ornamentos cefálicos ou corporais em um entre eles (Figura 11A) e com D Stretch (Figura 11B).

A separação desses humanos, de realismo figurativo bastante marcado, com o resto do dispositivo no abrigo contrasta com sua integração no dispositivo da cornija. Mas, nesse caso, o vínculo se faz com as representações animais de aspecto figurativo mais marcado do que o da maioria dos animais pintados no abrigo. Entretanto, na parte central do abrigo (metros 19-20 a 29-30, aí onde as ocupações foram as mais densas), a parede conserva um conjunto de grandes pinturas (essencialmente violetas)
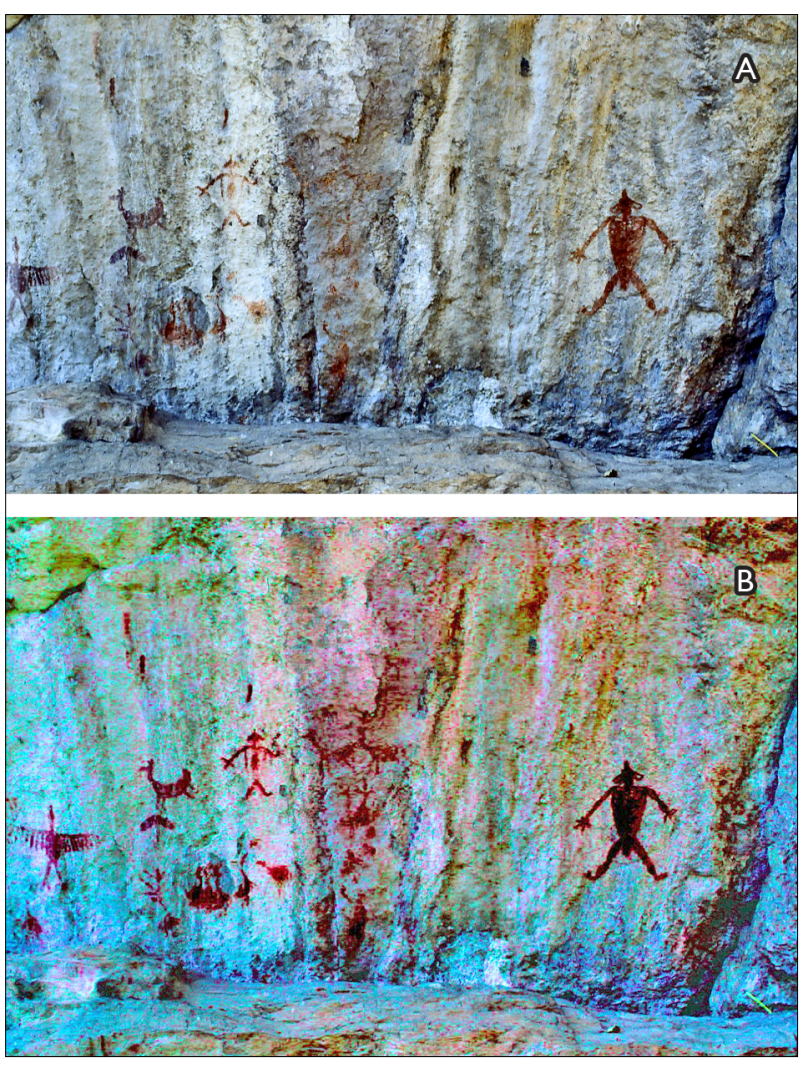

Figura 11. A) Painel de figuras cor vermelho-violeta: homens, aves e cervídeos, sinais no centro da cornija; B) painel com utilização D-Stretch filtro (YRD-Luminance Red Decorrelation). Fotos: Agueda Vilhena Vialou e Denis Vialou (1987) (A); Eric Robert (2019) (B).

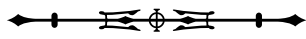


associando humanos e animais, partilhando formulações gráficas, com tendência realista bem marcada em certos casos, e outras extravagantes. A principal figura - poderse-ia considerar como a emblemática do dispositivo - é uma anta (1,05 m de comprimento) pintada de violeta, colocada a 3,50 m de altura no metro 21 (Figura 12A) com D-Stretch (Figura 12B). Com suas patas dobradas, as unhas marcadas, o perfil expressivo da cabeça, o volume corporal corresponde bem ao maior animal da região. Uma outra grande anta de cor avermelhada, situada um pouco abaixo, na parede (metro 39), apresenta um estilo figurativo realista (Figura 13), tanto mais sugerido, que um tipo de lança erguida por um humano, visto de face, indubitavelmente a perfura. Trata-se aí da única evocação de uma cena de caça no sítio.
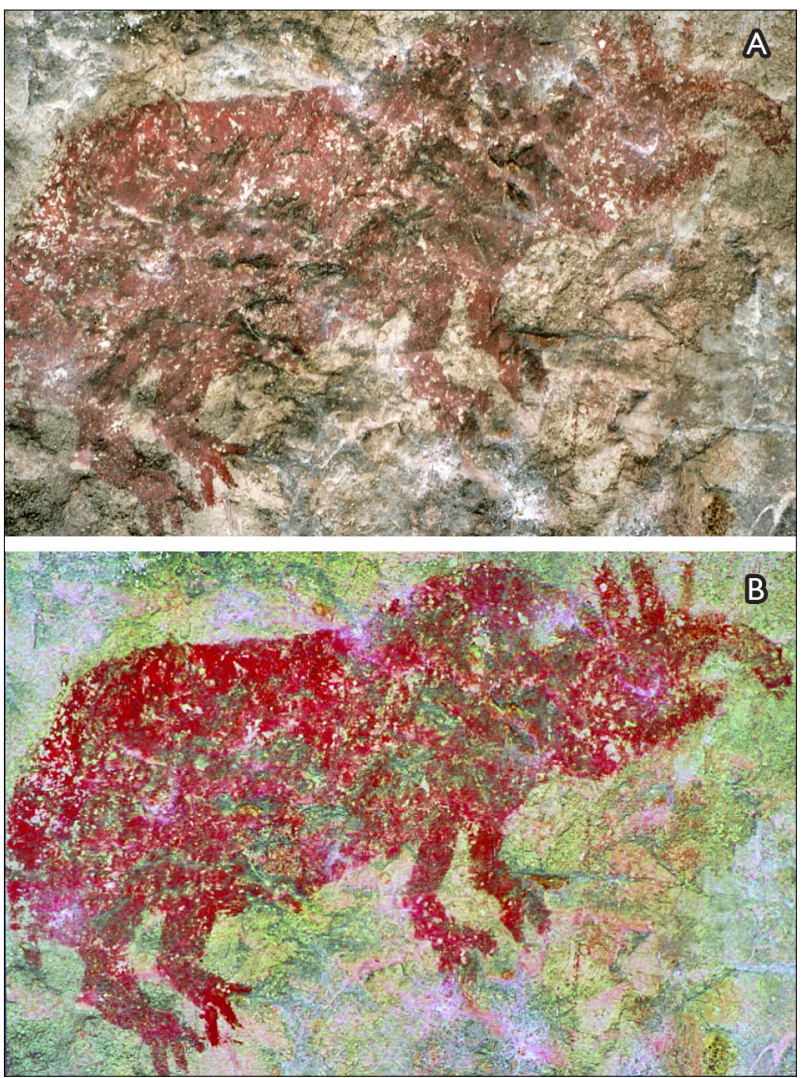

Figura 12. A) Anta (tapir), pintura de cor violeta, com cerca de 1 metro; B) anta com utilização D-Stretch filtro (YRD). Fotos: Agueda Vilhena Vialou e Denis Vialou (1987) (A); Eric Robert (2019) (B).
Um felino de cor violeta, colocado igualmente em posição alta na parede (metro 24), faz o contrapeso figurativo bastante expressivo à grande anta de cor violeta. Na parte mediana do registro pictural desse setor, duas outras grandes pinturas violetas, seres fantásticos, se distinguem da tendência realista da anta e do felino (Figura 14).

Pelos seus desenhos misturando certo realismo a um delírio figurativo, por sua expressão tecnoestilística de grandes figuras violetas em tintas uniformes, por suas localizações mais altas e no centro do abrigo, esse conjunto se destaca de todo o resto no dispositivo do abrigo. As justaposições e as superposições, nesse setor parietal, indicam que o conjunto precedeu as outras séries picturais. Poderia ser fundado pensar que tal conjunto monumental, espetacular, foi o primeiro a ser realizado no abrigo.

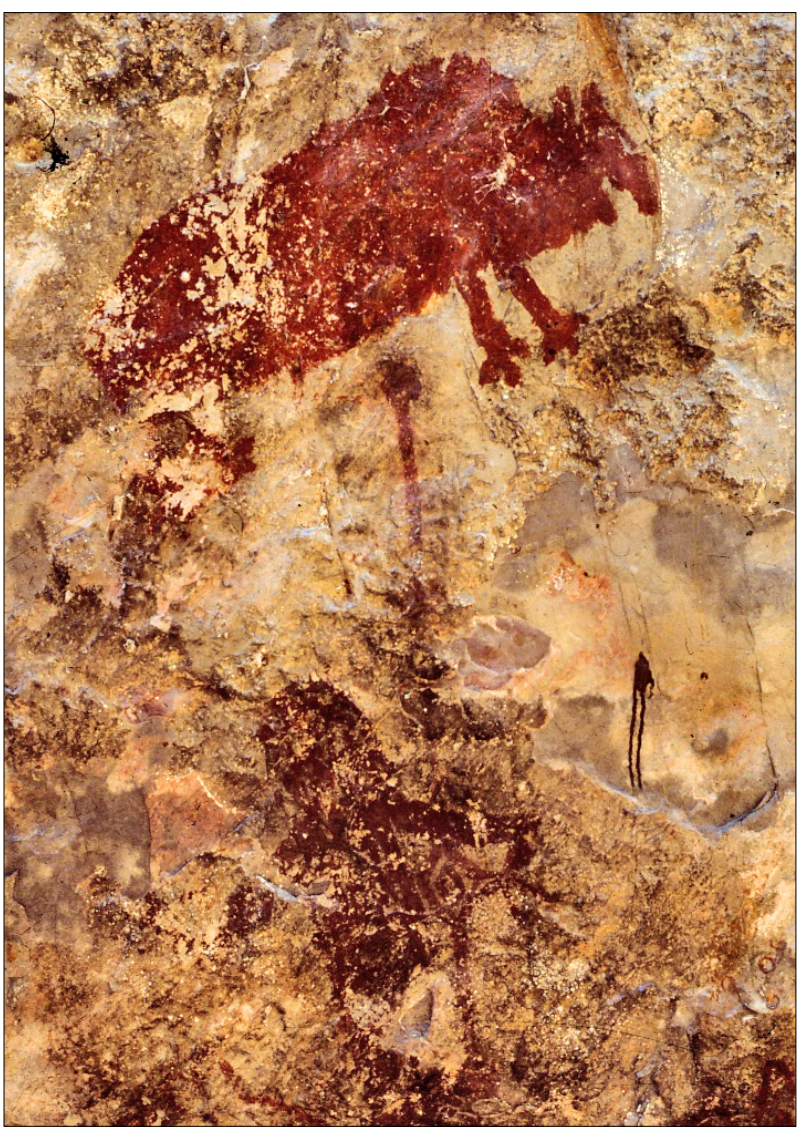

Figura 13. Cena de caça: figura humana com uma lança atingindo uma anta. Foto: Agueda Vilhena Vialou e Denis Vialou (1987).

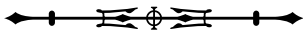


Bem diferente e de outra natureza figurativa são os pequenos desenhos, em tinta uniforme ou em contornos lineares, que fazem pensar em batráquios anuros ou em tartarugas, vistos de cima; vários entre eles apresentam formas que podem evocar seres humanos. Uma confusão gráfica nesse sentido afeta silhuetas em tinta uniforme ou em contornos, podendo se relacionar a lagartos vistos de cima ou a humanos vistos de face. Todas essas representações equívocas no plano figurativo são desprovidas de elementos anatômicos suficientemente discriminantes para assegurar suas identificações. Essa ambivalência de identificação interrogativa, ou essa ambiguidade figurativa da percepção visual da dezena de representações referidas, dispersas no dispositivo, simboliza talvez relações 'animistas' homem-animal,

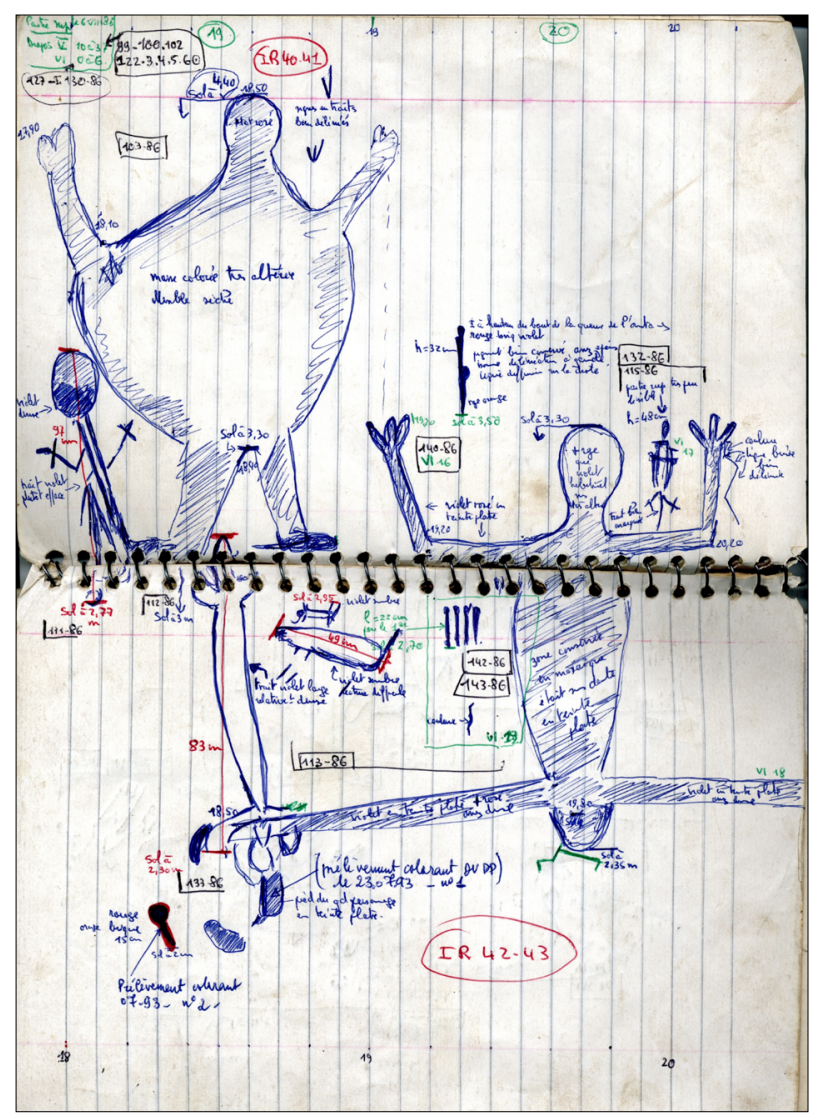

Figura 14. Plano diretor do dispositivo parietal com figuras fantásticas. Foto: Denis Vialou (1987). nessas sociedades de caçadores-coletores, denotando proximidades, e não oposições nítidas, como acontece nas sociedades que foram configuradas e impregnadas de religião e de racionalismo.

Entretanto, vários da quinzena de animais figurados no abrigo e a maior parte dos 38 animais da cornija se beneficiam de um estatuto figurativo suficientemente naturalista para escapar a toda leitura e a toda compreensão equívocas. As variações figurativas, indo até os limites da caracterização visual, dizem respeito aos cervídeos, quer dizer ao mais importante grupo zoológico (31 na cornija e 28 no abrigo). Essas variações afetam, em particular, os chifres do veado: alguns são aberrantes; outros estão reduzidos a formas pouco inteligíveis. Os membros estão frequentemente figurados artificialmente em movimento, tendo uma forma acentuada de vírgulas, projetando o animal para frente, como se estivesse correndo (Figura 15). No abrigo, os cervos estão dispostos em dois grupos apartados: 12 pintados de vermelho, seguindo em fila sobre 4 metros, bem no início do dispositivo. $\bigcirc$ segundo grupo, metros 13 a 2, conta com 16 indivíduos, pequenos e às vezes dispostos em fila. $O$ melhor exemplo disso é dado por quatro pequenos cervos em tinta uniforme vermelha brilhante, colocados em fila rente ao solo atual do abrigo. Os chifres detalhados

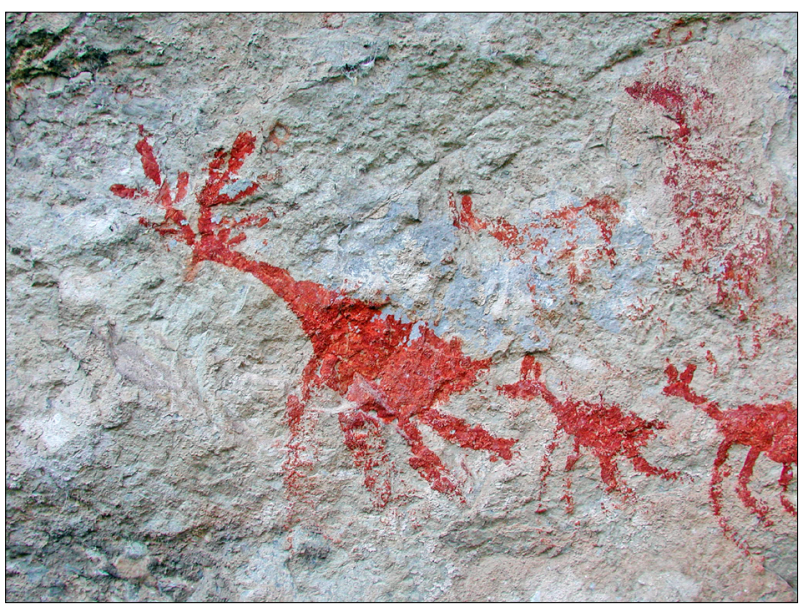

Figura 15. Cervídeos em posição de corrida, na cornija. Foto: Agueda Vilhena Vialou e Denis Vialou (2002).

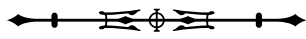


de um macho lhe conferem um status figurativo excepcional. Bem pequenos, naturalistas, encontram-se na parte baixa da parede, distanciados das representações densamente acumuladas acima, onde estão bem no alto as impressionantes grandes representações violetas: trata-se aqui dos dois começos da cadeia de representações figurativas animais de Santa Elina.

Os pássaros compartilham com os cervídeos uma orientação figurativa naturalista, mas segundo modelos diferentes. $\bigcirc$ abrigo conta com três pássaros nos metros 25-26: um deles parece planar como um gavião, os dois outros são vistos bípedes, de perfil. Existe também um outro pássaro bípede de corpo maciço, no metro 40, e uma ave pernalta no 45. O dispositivo da cornija reúne sete grandes pernaltas, vistos de face, asas abertas e emplumadas (Figura 16). Estão agrupados junto da

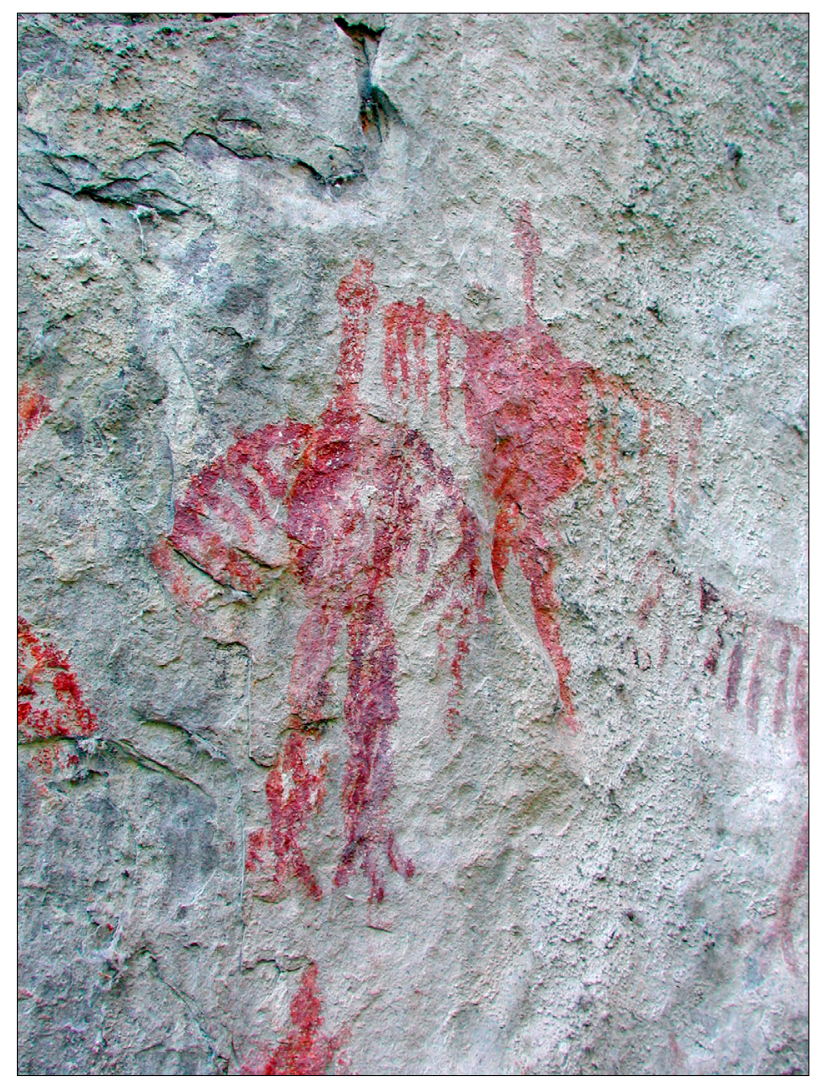

Figura 16. Pássaros pernaltas de asas abertas, pinturas na cornija. Foto: Agueda Vilhena Vialou e Denis Vialou (2002). manada de veados vermelhos, completamente a leste do dispositivo. Os vínculos semânticos entre cervídeos e os jaburus estão nitidamente valorizados por essa justaposição e pelos parentescos de suas expressões tecnoestilísticas.

Além de uma raia e de macacos (Figura 17A), com D-Stretch (Figura 17B) discretamente inseridos no centro do dispositivo do abrigo, notam-se cinco macacos na cornija, sendo dois realizados de formas deliberadamente extravagantes, pelo desenho de seus membros e rabos deformados (Figura 18). Situados não distantes do homem adornado, esses animais deformados voluntariamente mostram que o real e o fantástico se conjugam no imaginário de seus autores.
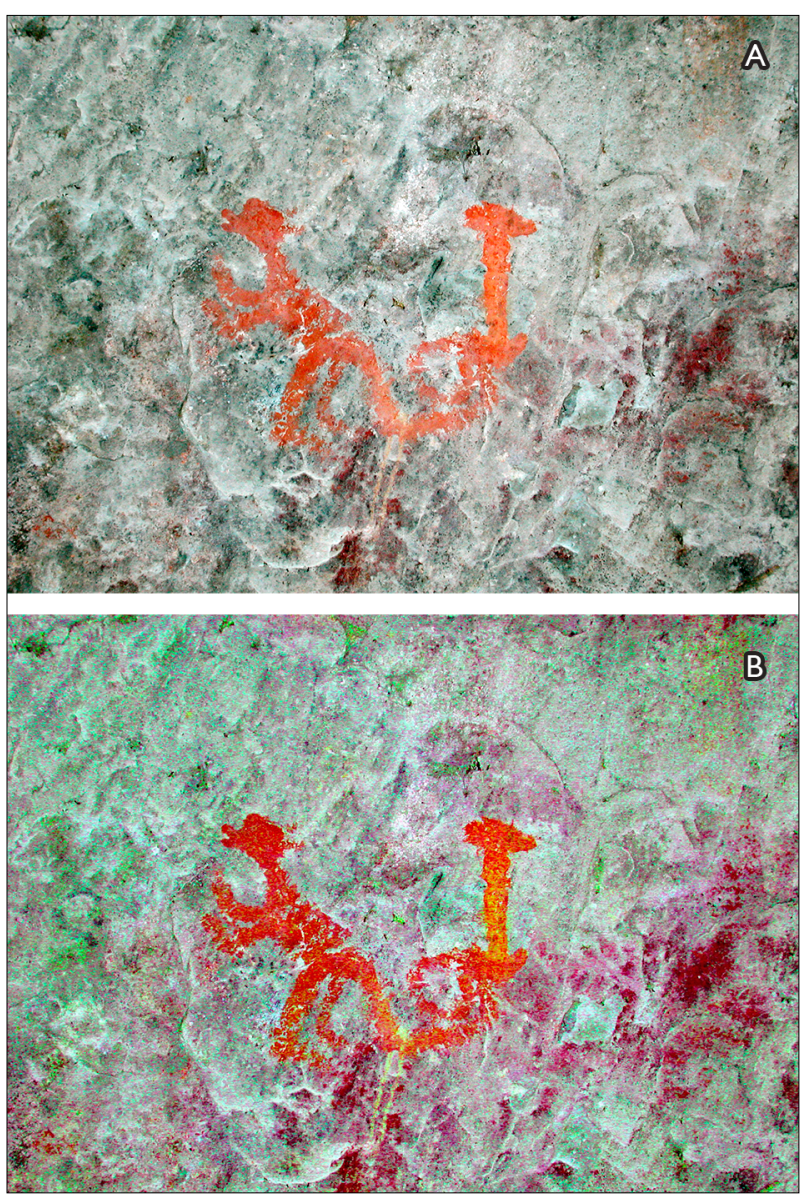

Figura 17. A) Macaco e flecha de cor vermelho-laranja; B) macaco e flecha com utilização D-Stretch filtro (YRD). Fotos: Agueda Vilhena Vialou e Denis Vialou (2002) (A); Eric Robert (2019) (B).

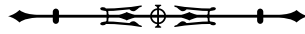


Uma boa centena de representações no abrigo e uma dezena de outras na cornija escapam a identificações exatas: quadrúpedes indeterminados, silhuetas não verdadeiramente humanas e ainda menos animais, três pés anormalmente digitados, desenhos não figurativos, não verdadeiramente assimiláveis a sinais ou motivos geométricos caracterizados. Esse conjunto disparate de representações estranhas ou incompletas, acumuladas principalmente na parte central do dispositivo do abrigo (metros 15-28), mostra que a construção simbólica do dispositivo de Santa Elina não se baseia na imitação do real nem em uma narração gráfica de vivências, nem em uma reprodução de acontecimentos vividos.

\section{ORNAMENTOS OU REPRESENTAÇÕES CORPORAIS}

Os objetos de ornamento encontrados na área habitacional do abrigo pertencem, em sua grande maioria, aos períodos mais recentes de ocupação, ao redor de 2.000 a 4.000 anos atrás. Tais adornos são colares, pulseiras, braçadeiras, estojos penianos, confeccionados seja em vegetais, seja em conchas, seja em osso, seja em rocha. Entretanto, foram encontrados, em cada período marcante da longa presença humana em Santa Elina, elementos significativos de manifestações simbólicas,

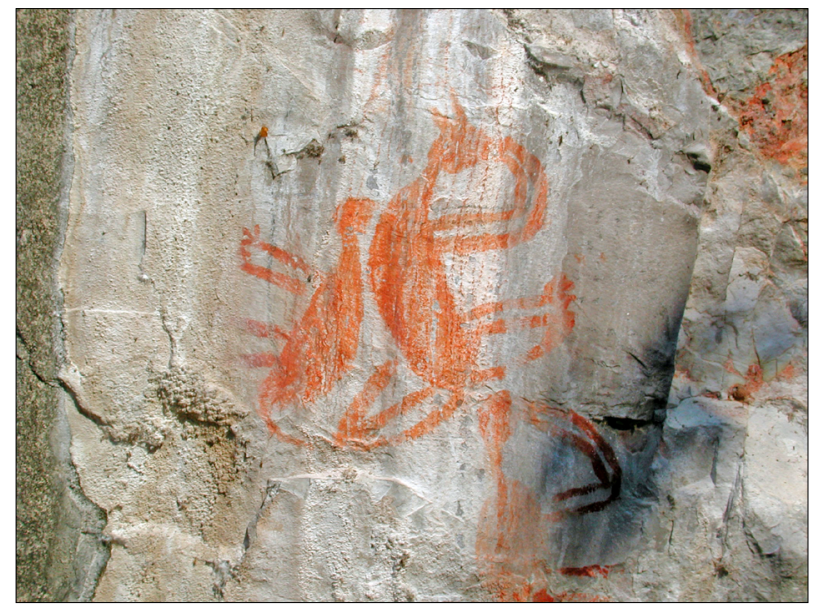

Figura 18. Dois macacos extravagantes. Foto: Agueda Vilhena Vialou e Denis Vialou (2002). como os tembetás, no Holoceno inicial, e os pingentes feitos de ossos de megafauna, no Pleistoceno, além dos corantes presentes ao longo de todas as ocupações.

\section{VEGETAIS TRABALHADOS}

A presença dos vestígios vegetais trabalhados, como trançados, cordões, nós, e sua localização nas proximidades das estacas poderiam se justificar dentro dessa perspectiva de local de habitação: pela organização e disposição das estacas de madeira, os objetos poderiam ser colocados e dependurados em um desses postes, que poderiam servir de jiraus, evitando o contato direto com o solo constituído de sedimento extremamente pulverulento.

As folhas ou os folíolos de palmeiras serviram para a confecção de braçadeiras, de estojos penianos, de sandáliasalpercatas, ornamentos esses que podem ser referidos a grupos indígenas atuais ou conhecidos pela literatura (Figura 19). Eles se encontram nos perímetros das aldeias Bororos ou dos Umutina a eles afiliados (Taveira, 2005).

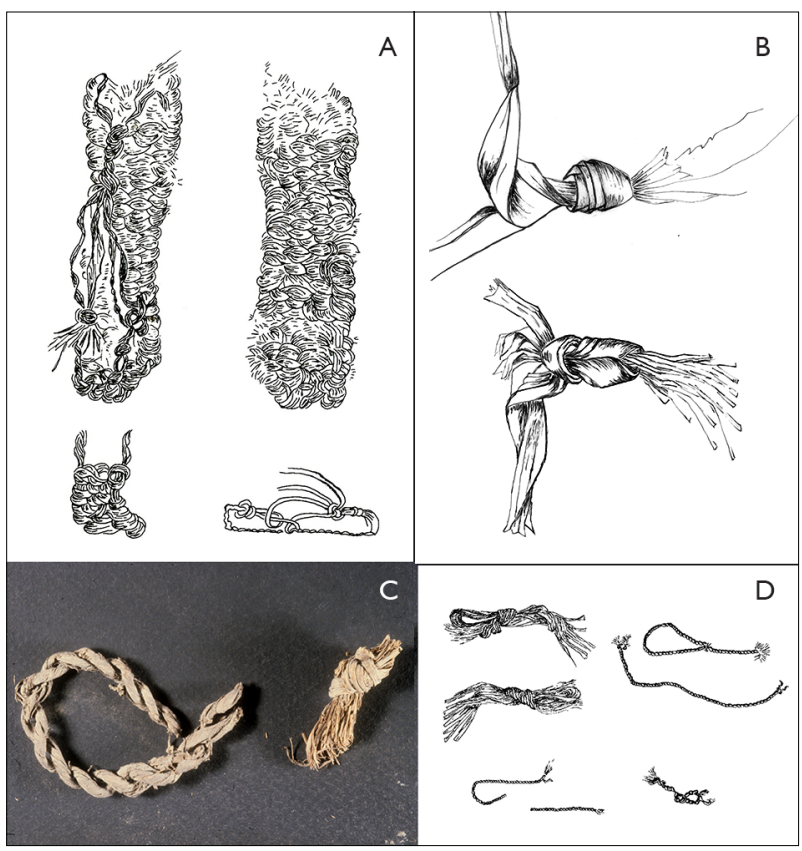

Figura 19. Vegetais trabalhados: A) sandália trançada; B) braçadeira; C) nó; D) cordões. Desenhos: Hélène Blanchot (1996). Foto: Ader Gotardo - Museu de Arqueologia e Etnologia da Universidade de São Paulo (MAE/USP, 2012) (C).

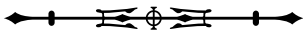


Seria quase possível reconstituir, pelas descobertas efetuadas, o grupo que habitou o abrigo há mais de 2.000 anos atrás com sua indumentária festiva: estojos penianos, braçadeiras, diferentes modelos de adornos peitorais, colares e tembetás, ornamentos labiais'.

As representações figurativas humanas pintadas na parede do abrigo permitem que seja feita uma analogia com o grupo familiar: de cor preta, uma cena de vários personagens e uma criança (Figura 10); na parte central do abrigo, indivíduo em cena de caça mostrando sua arma e o animal como troféu, no caso, uma anta (Figura 13). Na parte superior, na cornija, as representações são sempre masculinas. Elas contêm ornamentos na cabeça, tipo de corte de cabelo e penteado, perfuração auricular, evidências de um estreitamento dos músculos nas pernas e nos braços, sinal de utilização de braçadeiras e de 'tornozeleira' (Figura 20).

Cerca de cinquenta fragmentos de cordões, cordinhas, barbantes ou fios encontram-se dispostos ao longo do espaço habitacional, também de níveis de até 4.000 anos atrás. Sua confecção pode ter sido feita por torcedura em S ou Z (Blanchot; Amenomori, 2005). São cordões que poderiam também ser utilizados para sustentar contas ou pingentes e para serem amarrados como colares. A origem vegetal de alguns deles foi identificada por Béatrice Castel e Claudine Dauphin, do Institut Textile de France, em 1994, como espécies provenientes da América do Sul, em particular da Amazônia e da região do Mato Grosso: trata-se da piaçava (fibra da palmeira tucum), da roselle (Hibiscus sabdariffa) e da caratas ou bromélia. Os nós observados em algumas das cordinhas podem ser destinados a alongar um cordão muito curto.

Nove trançados, quinze nós de palha complexos, sendo alguns típicos de braçadeiras festivas, três estojos penianos de pequeno tamanho, com as dobraduras perfeitamente conservadas, e um par de sandálias-alpercatas

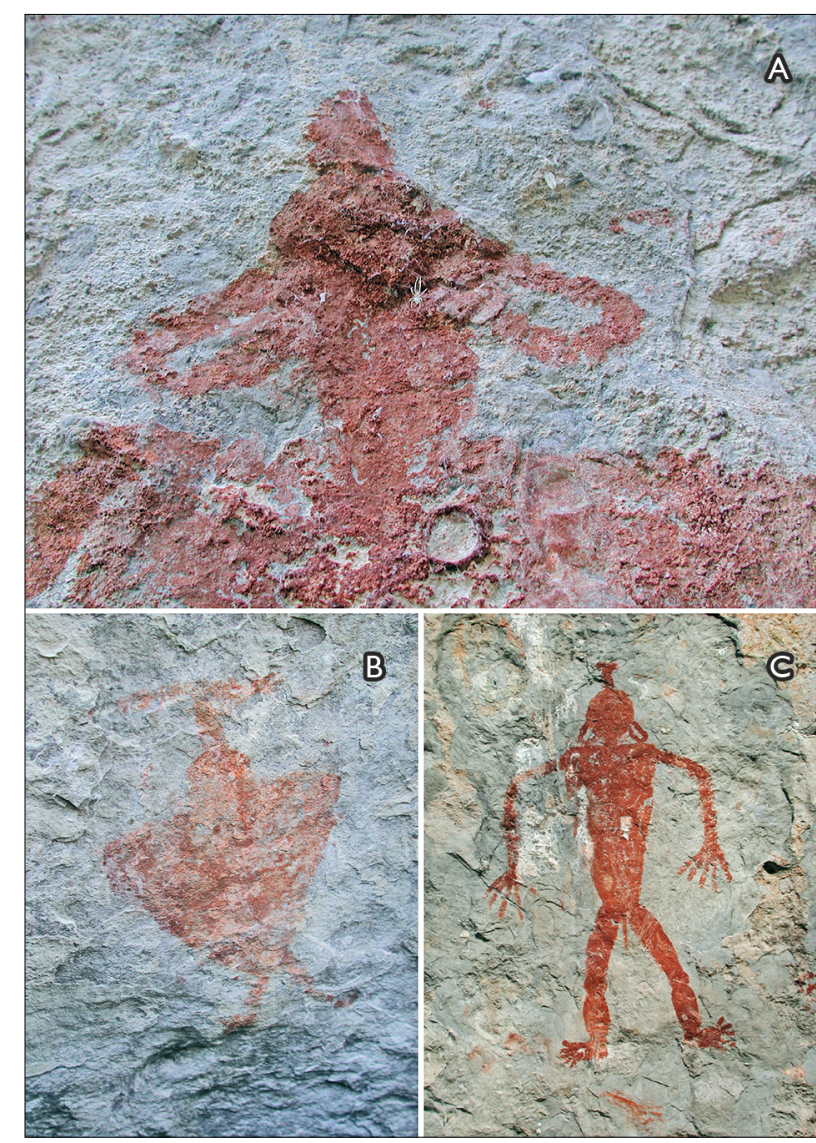

Figura 20. Pinturas da cornija. Representações de homens: enfeites auriculares, penteado, corpo disfarçado. Fotos: Agueda Vilhena Vialou e Denis Vialou (2002).

completam a diversidade de confecção de ornamentos a partir de vegetais trabalhados.

Várias fibras vegetais foram igualmente identificadas. No caso das pelotas ou maranhas (Taveira, 2005), cerca de 50 exemplares, esse agrupamento de fibras afinal, designado novelo de fibras, não teria tido uma explicação quanto à sua utilidade, se uma análise botânica não tivesse sido elaborada. De fato, as 'maranhas' são feixes de fibras de casca, esmagadas pela pressão e pelo 'esfregamento' com uma peça resistente (rocha?) pela mão do homem. Trata-se de planta conhecida por sua utilização farmacológica e também por seu efeito antiofídico.

\footnotetext{
1 Ver Taveira (2005, p. 237).
}

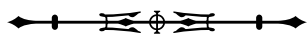


Chama-se cientificamente Aristolochia esperanzae (conhecida popularmente como papo-de-peru, jarrinha, milhome, flor-de-cachimbo), cuja flor tem um odor muito forte, de caráter picante (Ceccantini; Gussella, 2001).

\section{CONTAS E PINGENTES}

Ao longo de todas as ocupações, uma constante, desde 11.000 anos atrás, é a presença de moluscos, Megalobulimus gastropodos, Strophocheilus - identificação feita em 1988 por José Luiz Moreira Leite, do Museu de Zoologia da Universidade de São Paulo, e Figuti (2005). Quarenta contas elaboradas a partir desses moluscos possuem o mesmo padrão de confecção: as duas faces planas alisadas com um furo mediano. Não se pode dizer que há um tamanho padrão das contas de Santa Elina, mas elas são inferiores a 0,6 cm. Como foram feitas manualmente, cada conta se distingue da outra pelo seu contorno, por sua espessura, pelo seu orifício. Quanto à conservação, constata-se que algumas possuem uma de suas faces impregnada por microconcreções, confirmando infiltrações de percolamento do calcário em certos trechos do abrigo. Das contas encontradas, apenas três apresentam uma de suas faces manchadas de pigmento vermelho. Denota-se que não se trata de pintura das contas, mas de um contato que tiveram com outro objeto que contém o pigmento vermelho. É a face melhor conservada, apresentando uma superfície ainda polida e lustrosa, apenas com o acréscimo do pigmento (Figura 21).

Três vezes, as contas apresentam-se ainda atadas entre si: dois conjuntos de três contas coladas e um outro que possui quatro contas unidas por um cordão, tendo um laço em um dos bordos (Figura 22).

A presença dessas peças no sedimento extremamente fino e pulverulento provocou seu deslocamento tanto no sentido horizontal, devido a circulações e a reorganizações no espaço habitacional, pelas áreas de atividades fogueiras, armazenamento dos alimentos e a limpeza do chão -, como no sentido vertical, os objetos ligeiros e pequenos podendo penetrar no sedimento e atravessar

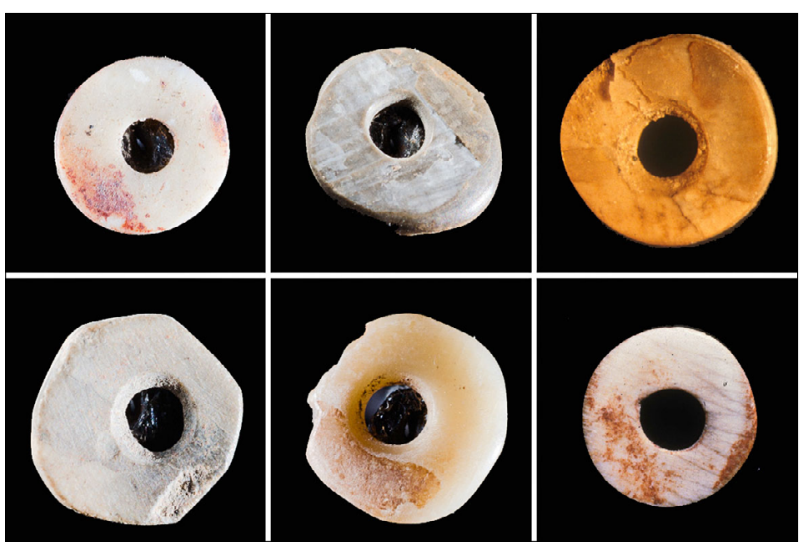

Figura 21. Contas feitas em conchas. Fotos: Agueda Vilhena Vialou e Denis Vialou (1996).

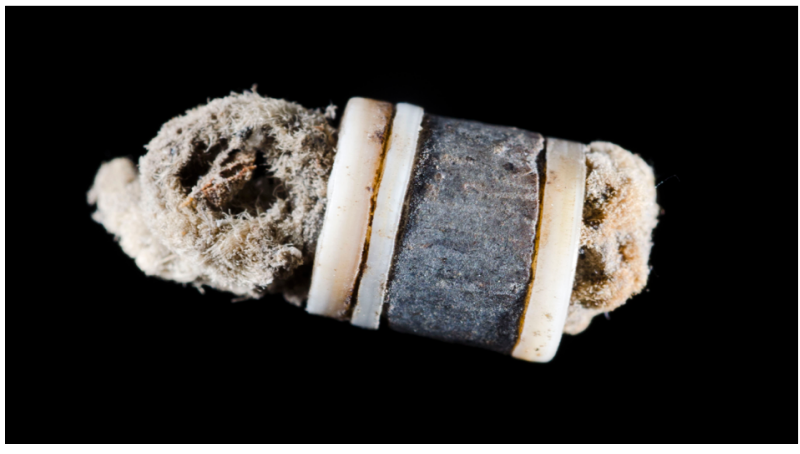

Figura 22. Contas atadas por uma cordinha. Foto: Ader Gotardo MAE/USP (2012).

camadas arqueológicas, mas sempre holocênicas. A localização preferencial dos objetos encontrados nos metros próximos da parede interna, a parede que abriga o sítio, se justifica pela própria ligeira inclinação do solo em direção sul, junto aos espaços que provocam uma vacuidade entre o solo e a parede.

Verifica-se, no Holoceno inicial, que em três placas de molusco, sumariamente retalhadas e com orificio apenas esboçado, poderia ser considerado um preparo de conta, uma pré-forma abortada, inacabada pela inequação do suporte.

Há três pingentes, sendo dois feitos de bivalves, conchas raras no abrigo, e um de gastrópodo. Eles constituem peças únicas nesse tipo de suporte, resultando em adornos de formas diferenciadas, e se encontram em níveis arqueológicos distintos (Figura 23).

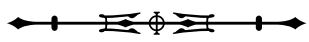



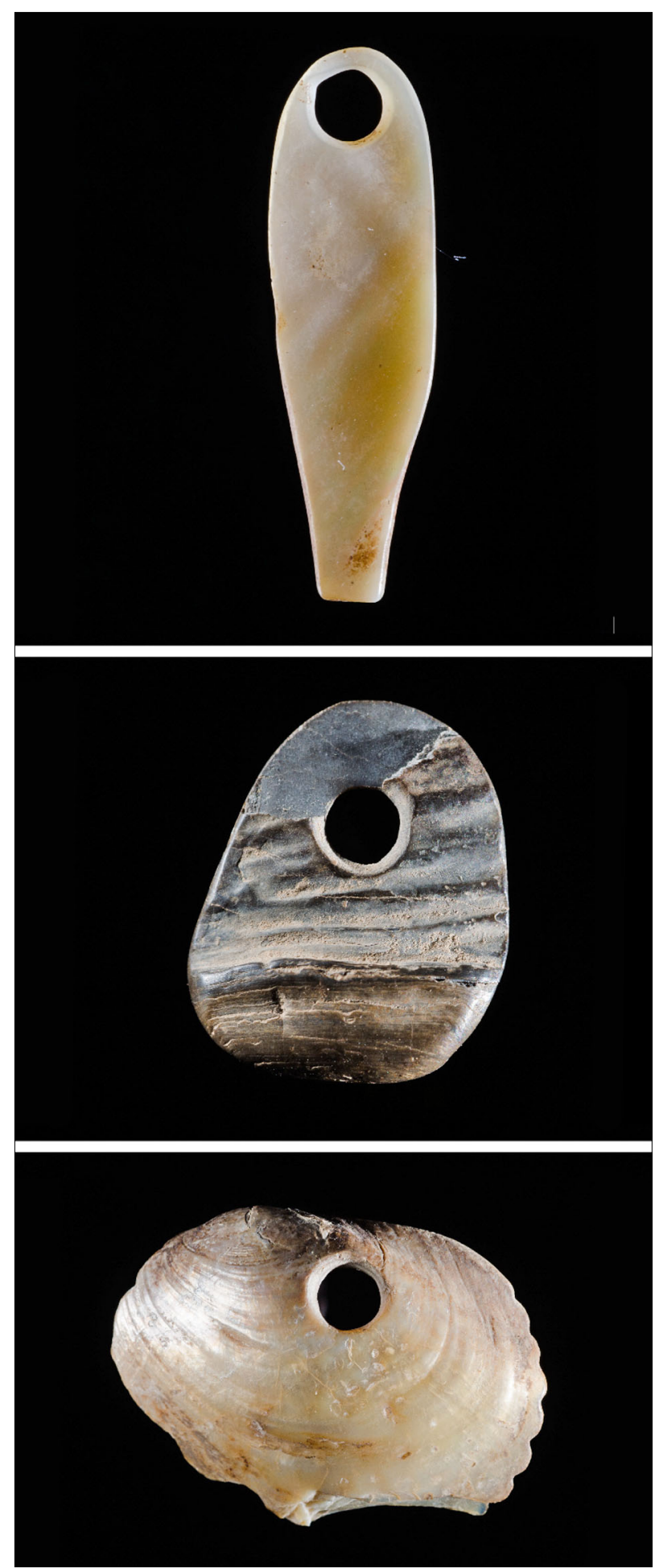

Figura 23. Pingentes feitos em conchas. Fotos: Ader Gotardo - MAE/ USP (2012).
O pingente (SEl 7368), do nível recente (cerca de 2.000 anos AP), com perfeita conservação da madrepérola, é um belo exemplo de adorno peitoral, de pingente solitário: peça delgada $(30 \times 9 \times 2 \mathrm{~mm})$, plana, lisa, estreita, com orifício largo na parte superior-proximal à mais larga da concha, reduzida por um trabalho que lhe dá um acabamento convexo. O meio-anel convexo, que serve para pendurar o pingente, é estreito em relação ao orifício. Polido em seus bordos, o adorno vai se afinando regularmente como uma gota. A parte distal tem uma base retilínea (quebrada?).

O pingente (SEl 3417), pequeno, de apenas $15 \mathrm{~mm}$, de gastrópodo (Strophocheilus - aruá-do-mato) do nível de cerca de quatro a cinco mil anos atrás, teve alteração na cor devido à queima, tornando-se cinza. Possui um orifício na parte superior-proximal mais estreita, deixando o restante da concha ainda com sua borda espessa.

O pingente (SEl 5311), do Holoceno médio, ao redor de 8.000 anos atrás, é uma bela concha com perfuração central em seu ápice e um denteamento regular, suave e sinuoso, no contorno de seu bordo. Apresenta desgaste pronunciado na parte superior-distal da concha, retirando o denteamento e com grande quebra desse bordo. Convexo na face externa e côncavo na face interna, esse molusco é do gênero Anodontites, conhecido como Prato ou Saboneteira, gênero endêmico da bacia do Paraná (identificação de Levy Figuti).

No nível Pleistocênico de 27.000 anos, com ocupações humanas associadas à megafauna, três adornos de osteodermes foram evidenciados. Esse período recuado para as ocupações nas Américas foi confirmado por datações: datas obtidas que são concordantes e comprovadas por laboratórios e métodos de datação diferentes: Urânio-tôrio (Museu Nacional de História Natural - MNHN, Paris), luminescência óptica estimulada (Washington University, USA) e por Carbono-14 em espectrometria de massa por aceleração (LSCELaboratoire des Sciences du Climat et de l'Environnement - Gif/Yvette) (Vilhena Vialou, 2011; Vialou et al., 2017).

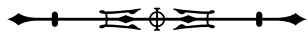


Trata-se da transformação de ossículos dérmicos, os osteodermes (Figura 24), que são abundantes no abrigo (cerca de 6.000). Fazem parte de uma grande quantidade de ossos (400), provenientes da parte dianteira do animal, a preguiça gigante, Glossotherium lettsomi. A atividade humana nesse período está atestada por mais de 300 objetos líticos presentes nesse nível. As intenções de um comportamento simbólico nesse mesmo espaço habitacional são reveladas através das abrasões e perfurações dessas três placas dérmicas osteodermes, por algumas das pequenas plaquetas retocadas em rocha calcária e em silícia, e pelas diminutas lascas retocadas, que poderiam ter servido na confecção dos adornos.

Os osteodermes encontrados in loco no solo habitacional de Santa Elina possuem naturalmente tamanhos reduzidos entre $5 \mathrm{~cm}$ e $3 \mathrm{~mm}$. São geralmente arredondados, com uma face lisa e outra com pequenas concavidades. Os adornos feitos nesses osteodermes mantiveram esses suportes iniciais, mas suas transformações resultaram em ornamentos de formas diferentes (Figura 25):

- SEl 6059 osteoderme, achatado por abrasões aplainando as faces, dissimulando completamente o aspecto globular do osteoderme. Duas reentrâncias em polos opostos indicam a confecção de orifícios, sendo que as extremidades finas e exteriores do orifício foram quebradas ou simplesmente roídas, como se verifica no contorno circular da peça (Vilhena Vialou, 1998);

- SEl 6368 apresenta uma perfuração bastante ampla, feita na parte superior das duas faces abrasadas do osteoderme, formando entre elas um bisel;

- SEl 6557 pequeno osteoderme, lustrado, uma perfuração afeta sua porção naturalmente em bisel. Um dos bordos em bisel é microdesgastado.

Trata-se de uma descoberta excepcional, não só pela presença humana, tão antiga no centro da América, como por essa prova de manifestação simbólica, pelos enfeites utilizando uma grande fauna, extinta devido às mudanças climáticas na transição Pleistoceno-Holoceno.

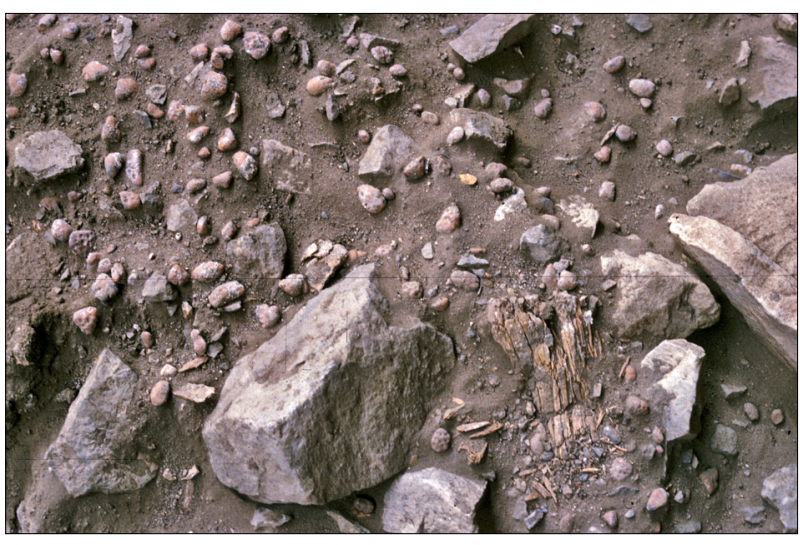

Figura 24. Vestígios ósseos alterados e concentração de osteodermes de Glossotherium lettsomi no solo datado de 27.000 anos. Foto: Agueda Vilhena Vialou e Denis Vialou (1998).
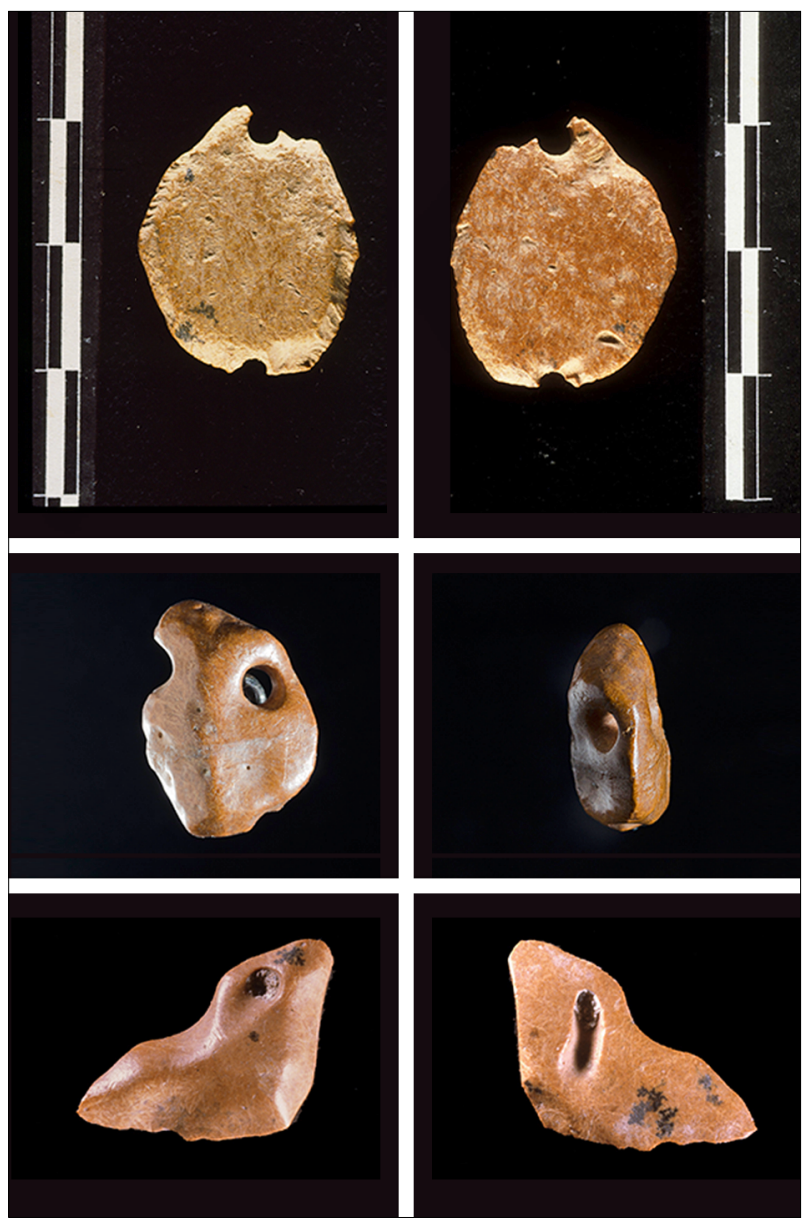

Figura 25. Três osteodermes perfurados como pingentes do nível de 27.000 anos. Fotos: Jean-Pierre Kauffmann - MNHN (1997) (osteoderme com escala) e Ader Gotardo - MAE/USP (2012).

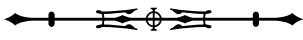




\section{ADORNOS LABIAIS}

Cinco 'prováveis' tembetás foram encontrados em uma mesma área, a leste do abrigo, entre os metros 19 e 25. Quatro deles pertencem ao mesmo período, ao redor de 6.000-7.000 anos atrás, e o quinto está situado em nível anterior, entre 8.000 e 9.000 anos. São peças originais, elaboradas com rochas exógenas ao abrigo. Pela escolha da rocha, particularmente diferente das demais do sítio, pelo seu tratamento de polimento dando-lhe formas distintas, os adornos labiais mostram-se únicos e provavelmente muito utilizados; são peças incompletas por quebra (pelo uso?).

Dois deles têm forma cônica, em rocha de cor cinza (SEl 781 e 789); outro é retangular, com faces planas em rocha zonada, bordos arredondados e ligeiramente convexos, as duas extremidades estão quebradas (SEl 3420); a peça SEl 4975 parece se enquadrar bem aos típicos tembetás, base reta, retangular e ligeiramente roliça; está quebrada de um dos lados, junto à extremidade proximal. E, enfim, o quinto tembetá, o mais antigo e o maior de todos (com $68 \mathrm{~mm}$ de comprimento, enquanto os outros não atingem $3 \mathrm{~cm}$ ), tem uma forma não habitual (SEl 1579): ligeiramente arcado, com duas faces planas, bordos arredondados, extremidade distal curva, com um plano inclinado. A extremidade proximal apresenta uma rondela plana, destacada por um sulco na base do objeto - percebe-se somente em um dos lados a quebra provavelmente de um apêndice lateral -, feito de rocha polida zonada, o que lhe dá um caráter decorativo. Pelos formatos singulares, pelas rochas utilizadas e também por suas dimensões, esses objetos poderiam corresponder aos tembetás, ornamentos labiais amplamente utilizados ainda hoje por vários grupos indígenas no Brasil (Figura 26).

Santa Elina contém, ainda, tanto pela fauna, com ossos de pássaros impregnados de pigmento, como pelos vegetais, pontas de madeira trabalhadas, elementos para se discorrer sobre o simbolismo desses objetos.

\section{HEMATITAS E BLOCOS COM PIGMENTOS}

Os objetos de ornamento, as representações parietais, são manifestações claras do universo simbólico. Mas, o que fica por detrás disso? O que permite suas realizações?

O pigmento de cor vermelha, tão descrito nos cerimoniais indígenas para suas pinturas corporais, provém do uso de plantas como o urucum. Mas essa cor de vegetal não subsiste no tempo, no caso dos dispositivos parietais. Além disso, não temos testemunhos conservados de restos ósseos humanos para comprovar a utilização do ocre, comumente descrito por pesquisadores e observadores de cerimoniais funerários.

No entanto, como na maioria dos abrigos rupestres, o vermelho, o laranja, o amarelo provêm de plaquetas de hematitas, nódulos de óxido de ferro (Vilhena Vialou et al., 1996). Essas plaquetas aparecem no pequeno córrego que circunda o afloramento calcário,
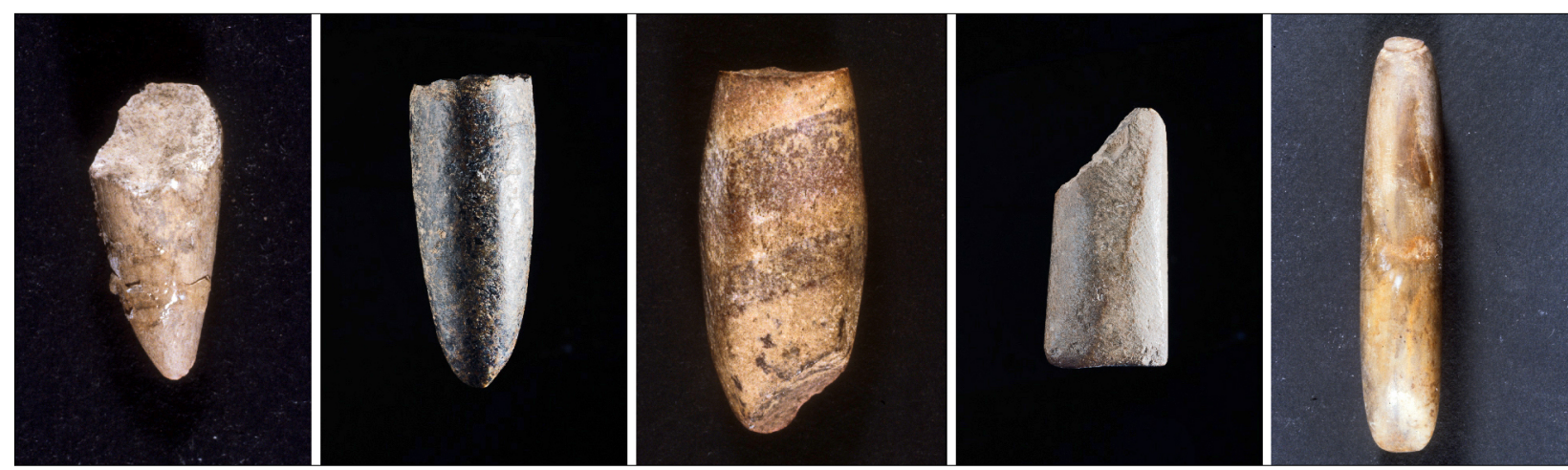

Figura 26. Cinco possíveis tembetás feitos em rochas exógenas ao abrigo. Fotos: Ader Gotardo - MAE/USP (2012).

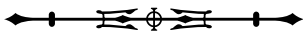


no vale onde se encontra o abrigo de Santa Elina. Elas foram trazidas ao local de habitação onde centenas (700) delas foram transformadas: raspadas, abrasadas, reduzidas em pó, para produzir a cor vermelha em outros suportes (D’Errico; Vilhena Vialou, 1999). Sua utilização nas paredes é manifestada pelos traços deixados em desenhos e pinturas efetuadas; igualmente pelas bem nítidas estrias nas plaquetas, demonstrando um vai e vem constante do gesto de abrasão.

Essa atividade de esfregamento da plaqueta de hematita, para reduzi-la em pó, foi verificada em dois locais da cornija: em concavidades naturais do chão calcário contendo marcas de pigmento vermelho. Trata-se de um espaço exíguo e um pouco vertiginoso, onde o preparo da pintura deveria se fazer ao pé da parede a ser pintada, evitando o trajeto 'perigoso', malabarístico. $\bigcirc$ artista deveria ficar no local, preparando o pigmento e realizando seus desenhos, sem muito transitar pela estreita cornija.

Esses vestígios, as hematitas, como corantes, e os blocos e as lascas de calcário manchados de pigmento, em geral vermelho, concernem todos os níveis arqueológicos, do mais antigo, pleistocênico, de 27.000 anos atrás, aos mais recentes, de apenas 1.800 anos atrás.

Suas frequências mais marcantes foram registradas particularmente em dois níveis: o nível do solo pavimentado, de 7.000 anos atrás, e o das fogueiras, datado ao redor de 11.000 anos.

Assim, na área do abrigo com a sequência das ocupações, as marcas deixadas em blocos são numerosas, 600 blocos, lascas e fragmentos em rocha calcária, presentes ao longo de toda a estratigrafia (Figura 27).

O nível mais antigo, datado de 27.000 anos, contém algumas hematitas, oito, bem desgastadas, com marcas evidentes de sua utilização e redução até chegar ao tamanho de um pequeno dadinho de $2 \mathrm{~cm}$ (Figura 28). $O$ solo dessas ocupações continha mais de 300 objetos líticos, entre lascas e utensílios, e uma associação direta com a megafauna, Glossotherium lettsomi (Vilhena Vialou, 2011). Algumas - uma dezena - dessas lascas em calcário apresentam-se marcadas pelo esfregamento do pigmento vermelho.
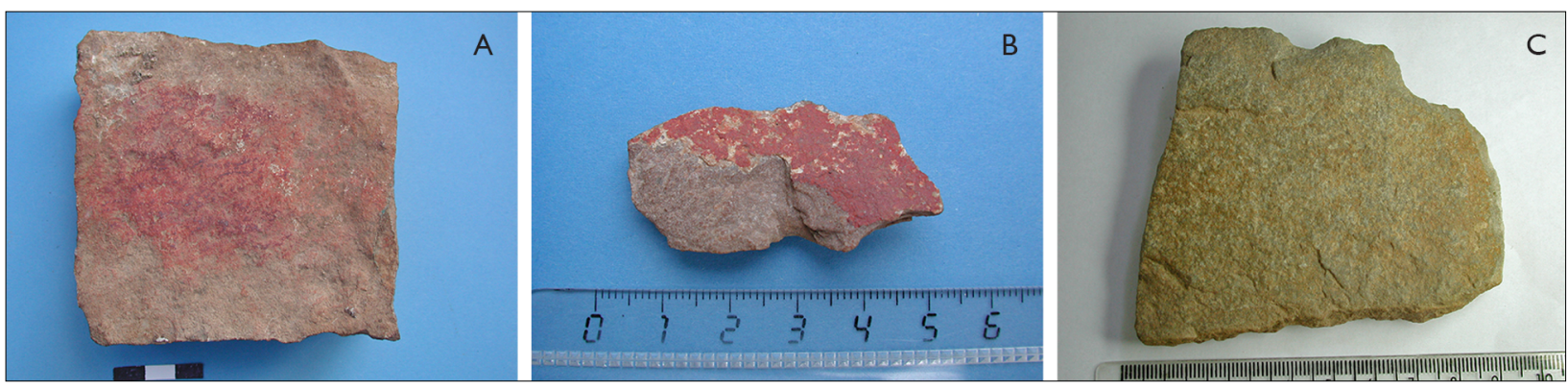

Figura 27. A) Pigmento vermelho em bloco de 11.000 anos AP; B) lasca de 3.000 anos AP; C) utensílio calcário de 27.000 anos AP. Fotos: Agueda Vilhena Vialou e Denis Vialou (2012).
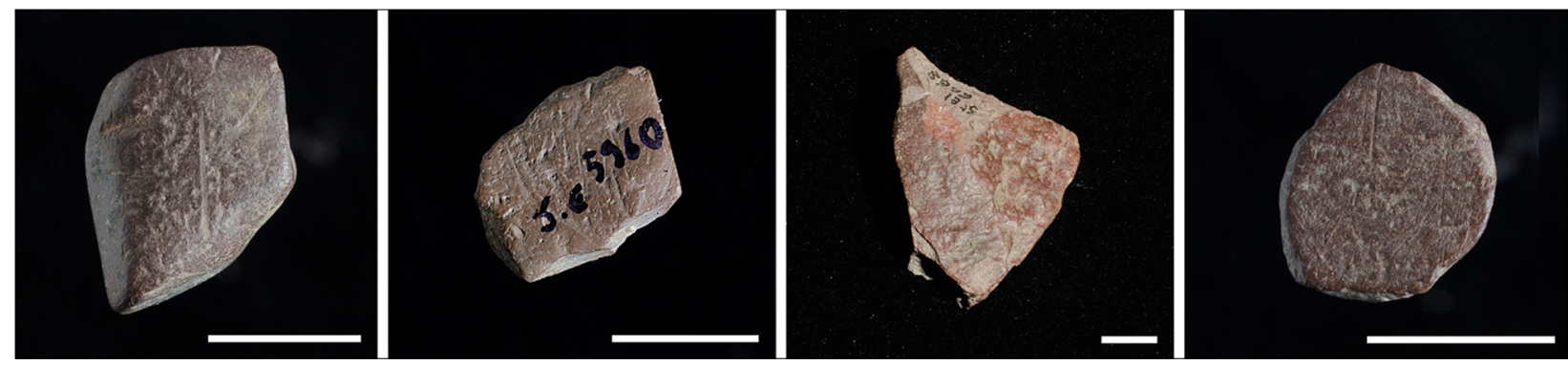

Figura 28. Hematitas com marcas de utilização do nível datado de 27.000 anos atrás. Fotos: Ader Gotardo - MAE/USP (2012).

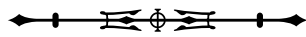


Os níveis de ocupações da transição PleistocenoHoloceno contêm intensas fogueiras em associação direta com manipulações de pigmentos vermelhos. Uma sequência de fogueiras atingindo $3 \mathrm{~m}$ de comprimento sobre 1,50 m de largura, ao longo da parede interna do abrigo, foi datada entre 10.000 e 11.000 anos antes do presente. Essa utilização do espaço perdurou por cerca de um milênio. As fogueiras constituídas de placas de calcário e de uma grande quantidade de carvões têm um sedimento fino cinza-marrom, que indica sua composição decorrente de mistura intensa com as cinzas do fogo. Essa área apresenta-se circundada de blocos calcários maiores, $20 \times 10 \times 5 \mathrm{~cm}$, sendo alguns deles manchados de cor vermelha, formando um limite do espaço e uma proteção das fogueiras.

Um dos níveis arqueológicos, datado de 7.000 anos AP, possui solo com blocos calcários manchados intensamente de cor vermelha, com 10 a $20 \mathrm{~cm}$ de dimensão. Considerou-se como uma pavimentação separando os níveis anteriores, soltos e arenosos, dos níveis mais recentes, com sedimento formado pela ação de intensas fogueiras, compostas de carvões e cinzas, resultando em um sedimento de pó fino, completamente antropizado.

\section{MULTIPLICIDADES DAS OCUPAÇÕES DO ABRIGO SANTA ELINA}

Quase que um milhar de representações pintadas e desenhadas nas paredes do abrigo e da cornija são o testemunho de uma multiplicidade de fases de elaboração do dispositivo rupestre. A sequência contínua de ocupações no abrigo, desde a passagem Pleistoceno-Holoceno, e as duas séries distintas de ocupações no Pleistoceno testemunham a multiplicidade de circulações de vindas e de moradias no abrigo. É inconcebível que esta dupla multiplicidade seja a ocorrência de uma única sociedade, de uma mesma origem populacional da região, composta de cadeia de montanhas com altitude fazendo barreira a uma depressão sedimentar, a qual é totalmente aberta no centro do continente sul-americano.
A única descontinuidade cronológica manifestada é a que se inscreve no Pleistoceno: uma ausência de ocupação estruturada entre duas grandes ocupações, datadas de mais de quinze milênios de distância, que oferecem, no entanto, traços comuns ou similares: a coexistência, no meio-refúgio ecologicamente favorável, de homens com uma megafauna próxima de sua extinção.

A descontinuidade cultural principal é a que separa as ocupações do Pleistoceno às do Holoceno, fortemente compactadas a partir de 8.000-7.000 anos AP até o abandono do sítio. Uma tal ruptura entre os dois conjuntos não é atestada no espaço simbólico parietal: distinguemse aí séries de execuções, mas não uma série que seria pleistocênica, fora das outras, posteriores.

Comportamentos simbólicos, na mais antiga ocupação do sítio, são demonstrados por alguns objetos excepcionais: os três osteodermes recortados e perfurados, a dezena de hematitas reformatadas e trazendo marcas de estrias, algumas pequenas lascas e plaquetas calcárias, contendo marcas de pigmentos. É pouca coisa, mas suficientemente demonstrativa de atividades de ordem social-simbólica, realizadas no sítio. A criação de representações parietais por esses grupos vindo habitar o sítio, bem naturalmente protegidos por seu isolamento no interior da serra, poderia ser considerada: ela não é verificável.

A disjunção topográfica entre o 'abrigo' (propriamente dito) e a 'cornija' não significa uma separação temporal entre os dispositivos parietais. De fato, muitas das temáticas figurativas contidas nessas diferentes áreas são comuns e, às vezes, similares: o caso mais surpreendente é o das representações humanas, semelhantes e ao mesmo tempo diferentes. Os humanos pintados de preto no abrigo estão agrupados em sua extremidade oriental, oposta ao acesso à cornija. Os humanos vermelhos da cornija não estão agrupados; eles descompõem, em alinhamento, a parte ocidental do dispositivo. Eles estão aí acompanhados por esquisitos macacos e cervídeos, nem todos realistas. Essa dupla temática dos humanos no sítio é singularmente enriquecida pela figuração dos ornamentos cefálicos. 
Assim, desenvolve-se uma relação provável, pelo menos plausível, entre a simbólica corporal parietal e a simbólica corporal atestada pelos ornamentos evidenciados no sítio, os quais pertencem preferencialmente aos níveis de ocupações datados por volta de 4.000-2.000 anos AP. Estão concentrados no flanco oeste da parte central do abrigo (metros 31-36), o mais denso em ocupações e em representações, as quais, por sua vez, estão dominadas pelos sinais (e alguns motivos) particularmente pontuados, lineares e angulares (flechas). Pode ser que esses sinais simples façam eco à sinfonia dos desenhos corporais regularmente praticados pelos ameríndios. Poderia existir certa correspondência entre essas simbólicas corporais, as pintadas e as praticadas em relação aos que viviam no sítio; ela se situaria no patamar cronológico dos últimos milenares.

Para as representações humanas, o parentesco estilístico de figurações de cervídeos faz uma ligação entre os dois dispositivos. Trata-se de pequenas pinturas em tinta uniforme, agrupadas em filas e colocadas separadamente das aglomerações mais densas de representações animais e de sinais. Assim, humanos e cervídeos têm um tratamento paralelo para suas inscrições em cada dispositivo.

As maiores figuras violetas, concentradas na altura no centro do dispositivo do abrigo, formam um conjunto homogêneo por suas dimensões e pela utilização em tinta uniforme em cor violeta, bem distinta das vermelhas, das marrons e das pretas. Sua temática associa animais e criaturas fantásticas, confundindo humanos e animais. A expressão estilística tosca, salvo a da grande anta, distanciaas de um naturalismo figurativo, mais reservado a pequenas representações, principalmente dos cervídeos. Esse conjunto, imediatamente perceptível como tal, poderia bem ser considerado como o mais antigo do dispositivo. Poderia também ser que os sinais próximos, desenhados em violeta, pertencessem à mesma série. Parece também estar na mesma categoria o casal de 'orantes', desenhado por um traço, em violeta, colocado sob a grande anta naturalista da mesma cor.
As representações pintadas e desenhadas em vermelho abundam nos dois dispositivos. As numerosas nuanças de vermelho resultam da preparação do corante sob formas mais ou menos pastosas ou líquidas. Não é possível discernir séries distintas nas representações vermelhas, figurativas ou abstratas, em geral, também incompletas ou indeterminadas.

As hematitas, facilmente coletadas nos pequenos riachos próximos ao sítio, trazem marcas de estrias de esfregamentos e/ou apresentam pelo menos um bordo abrasado, são mais abundantes em dois períodos de ocupações, entre 11.000-9.000 anos atrás e entre 7.000-6.000 anos atrás, em comparação com os outros mais recentes ou mais antigos. Acrescentam-se a isso cerca de 600 blocos ou lascas de calcário marcados de pigmentos vermelhos: sejam marcas de tampões, mais ou menos circulares ou amplos, sejam dos tracejados lineares, mais ou menos borrados, não permitindo uma classificação morfológica precisa. Esses blocos não retocados (de volumes paralelepipédicos, entre 10 e $20 \mathrm{~cm}$ de lado) foram coletados nos abrigos ou nas proximidades imediatas. Uma boa maioria entre eles formava um tipo de pavimentação na ocupação várias vezes datada ao redor de 7.000-6.000 anos AP. A cor vermelha de preparação fácil e rápida teve, assim, uma função simbólica preponderante no interior dos dispositivos do abrigo, da cornija e sobre os grandes blocos em frente ao abrigo. Essa cor foi igualmente dominante nas ocupações do Holoceno médio e recente.

Em definitivo, cruzando com muita prudência os dados parietais e os fornecidos pelas diferentes sequências de ocupações, tornar-se-ia razoável ordenar, em grandes linhas, a história do sítio: inicialmente (e ainda), isolado geograficamente em seu refúgio de montanha e culturalmente em sua confrontação econômica homemmegafauna; em seguida, ligado aos povoamentos do final do Pleistoceno-início do Holoceno e de onde a economia lítica contém uma dezena de peças bem elaboradas, os plano-convexos, de matérias-primas bem escolhidas e raras no abrigo: sílex, arenito, calcário fino. Diferentes fases 
de construção dos dispositivos parietais acompanham, em seguida, as ocupações, conduzindo as populações indígenas do planalto, bem próximas da geopolítica brasileira histórica.

O presente texto analisa os comportamentos simbólicos identificados no abrigo de Santa Elina, em diferentes etapas de suas ocupações, sejam pleistocênicas, seja da passagem Pleistoceno-Holoceno, seja durante todo o Holoceno. Esse indicador cultural, proveniente de uma pesquisa contextualizada, é uma contribuição aos recentes trabalhos de nosso grupo sobre primeiros povoamentos no Brasil central, apresentados neste número.

\section{AGRADECIMENTOS}

As pesquisas no abrigo rupestre de Santa Elina, de 1984 a 2005, feitas em colaboração com o colega Levy Figuti, professor do MAE/USP, só puderam ser realizadas graças a apoios substanciais e diversos. Agradecemos primeiramente à família Botelho Campos, proprietária da fazenda Santa Elina, onde se situa o abrigo, pela cordial e generosa acolhida anual a toda equipe, disponibilizando operários que lá trabalhavam. Evidentemente, seguem nossos cumprimentos a todos que participaram desses anos de pesquisas, tanto os pesquisadores científicos como os numerosos estagiários, contribuindo coletivamente à descoberta, à análise e à interpretação da região e de seus vestígios. Uma pesquisa dessa envergadura necessitou de apoios institucionais e financeiros: Ministério de Relações Exteriores da França, pela Comissão Consultiva das Escavações no Estrangeiro; Muséum National d'Histoire Naturelle, Paris; Museu de Arqueologia e Etnologia da Universidade de São Paulo; Universidade Federal de Mato Grosso; Fundação de Amparo à Pesquisa do Estado de São Paulo; Prefeitura de Jangada; bem como apoios espontâneos de particulares. Este artigo faz parte de reflexões oriundas do grupo de pesquisas da Coordenação de Aperfeiçoamento de Pessoal de Nível Superior, Comitê Francês de Avaliação da Cooperação Universitária com o Brasil (CAPES/COFECUB), intitulado "O povoamento inicial da América visto a partir do contexto arqueológico brasileiro", cujo número do processo é CAPES/COFECUB 840/15. Em conclusão, louvamos a iniciativa do colega Claide de Paula Moraes, pelo incentivo a essa publicação.

\section{REFERÊNCIAS}

ALVARENGA, Carlos José Souza de. Contexto geológico da Serra das Araras. In: VILHENA VIALOU, Agueda (org.). Pré-história do Mato Grosso. São Paulo: EDUSP, 2005. p. 85-86. (Santa Elina, v. 1).

BENABDELHADI, Mohammed. Contribuição da sedimentologia e da micromorfologia para o conhecimento dos sítios pré-históricos. In: VILHENA VIALOU, Agueda (org.). Pré-história do Mato Grosso. São Paulo: EDUSP, 2005. p. 113-124. (Santa Elina, v. 1).

BLANCHOT, Hélène; AMENOMORI, Sandra Nami. Levantamento dos vestígios vegetais do abrigo rupestre de Santa Elina. In: VILHENA VIALOU, Agueda (org.). Pré-história do Mato Grosso. São Paulo: EDUSP, 2005. p. 211-214. (Santa Elina, v. 1).

CARTELLE, Castor. A Preguiça-terrícola de Santa Elina. In: VILHENA VIALOU, Agueda (org.). Pré-história do Mato Grosso. São Paulo: EDUSP, 2005. p. 159-162. (Santa Elina, v. 1).

CECCANTINI, Gregório Cardoso Tápias. A cobertura vegetal associada ao abrigo rupestre. In: VILHENA VIALOU, Agueda (org.). Pré-história do Mato Grosso. São Paulo: EDUSP, 2005. p. 125-138. (Santa Elina, v. 1).

CECCANTINI, Gregório Cardoso Tápias. Madeiras arqueológicas do abrigo rupestre Santa Elina M. T. 2002. Tese (Doutorado em Botânica) - Instituto de Biociências, Universidade de São Paulo, São Paulo, 2002.

CECCANTINI, Gregório Cardoso Tápias; GUSSELLA, Luciana Witoviski. Os novelos de fibras do abrigo rupestre Santa Elina (Jangada, MT, Brasil): anatomia vegetal e paleoetnobotânica. Revista do Museu de Arqueologia e Etnologia, São Paulo, n. 11, p. 189-200, 2001. DOI: https://doi.org/10.11606/issn.2448-1750. revmae.2001.109417.

D'ERRICO, Francesco; VILHENA VIALOU, Agueda. Colorant reduction sequences at the rock art of Santa Elina (Mato Grosso, Brazil). In: INTERNATIONAL ROCK ART CONGRESS IFRAU, 1999, Torino, Itália. Anais [...]. Itália, 1999.

ETCHEVARNE, Carlos. Escrito na pedra: cor, forma e movimento nos grafismos rupestres da Bahia. São Paulo: Odebrecht, 2007.

FEATHERS, James. Datação por Luminescência Óptica Estimulada. In: VILHENA VIALOU, Agueda (org.). Pré-história do Mato Grosso. São Paulo: EDUSP, 2005. p. 55-58. (Santa Elina, v. 1).

FIGUTI, Levy. A arqueofauna do sítio de Santa Elina: nota preliminar. In: VILHENA VIALOU, Agueda (org.). Pré-história do Mato Grosso. São Paulo: EDUSP, 2005. p. 155-158. (Santa Elina, v. 1). 
FONTUGNE, Michel; HATTÉ, Christine; NOURY, Claude. Quadro cronológico. In: VILHENA VIALOU, Agueda (org.). Pré-história do Mato Grosso. São Paulo: EDUSP, 2005. p. 103-106. (Santa Elina, v. 1).

ISNARDIS, Andrei. Interações e paisagens nas paredes de pedra: padrões de escolha de sítio e relações diacrônicas entre as Unidades Estilísticas de grafismos rupestres do vale do Peruaçu. Arquivos do Museu de História Natural e Jardim Botânico, Belo Horizonte, v. 19, p. 319-368, 2009.

KAMASE, Luciane Miwa. Distribuição das estacas de madeira no sitio arqueológico de Santa Elina (M.T.). 1999. Trabalho de Conclusão de Curso (Bacharelado em Geografia) - Universidade de São Paulo, São Paulo, 1999.

ROSS, Jurandir Luciano Sanches. Contexto geomorfológico do sítio de Santa Elina. In: VILHENA VIALOU, Agueda (org.). Pré-história do Mato Grosso. São Paulo: EDUSP, 2005. p. 81-84. (Santa Elina, v. 1).

SCHEEL-YBERT, Rita; SOLARI, Maria Eugenia. Análise dos macrorrestos vegetais do setor oeste: antracologia e carpologia. In: VILHENA VIALOU, Agueda (org.). Pré-história do Mato Grosso. São Paulo: EDUSP, 2005. p. 139-147. (Santa Elina, v. 1).

TAVEIRA, Edna Luísa de Melo. Análise do material de fibras e palhas vegetais trabalhadas. In: VILHENA VIALOU, Agueda (org.). Préhistória do Mato Grosso. São Paulo: EDUSP, 2005. p. 215-239. (Santa Elina, v. 1).
VIALOU, Denis; BENABDELHADI, Mohammed; FEATHERS, James; FONTUGNE, Michel; VILHENA VIALOU, Agueda. Peopling South America's centre: the late Pleistocene site of Santa Elina. Antiquity, Cambridge, v. 91, n. 358, p. 865-884, Aug. 2017. DOI: https://doi.org/10.15184/aqy.2017.101.

VIALOU, Denis. Representações rupestres. In: VILHENA VIALOU, Agueda (org.). Pré-história do Mato Grosso. São Paulo: EDUSP, 2005. p. 245-254. (Santa Elina, v. 1).

VILHENA VIALOU, Agueda. Occupations humaines et faune éteinte du Pléistocène au centre de l'Amérique du Sud: l'abri rupestre Santa Elina, Mato Grosso, Brésil. In: VIALOU, Denis (ed.). Peuplements et Préhistoire en Amérique. Paris: Comité des travaux historiques et scientifiques, 2011. p. 193-208. (Documents Préhistoriques).

VILHENA VIALOU, Agueda (org.). Pré-história do Mato Grosso. São Paulo: EDUSP, 2005. (Santa Elina, v. 1).

VILHENA VIALOU, Agueda. Une pendeloque taillée dans un os de Glossotherium. In: ENCYCLOPAEDIA universalis. Paris: Universalia, 1998. p. 267.

VILHENA VIALOU, Agueda; BADU, Helena; D'ERRICO, Francesco; VIALOU, Denis. Les colorants rouges de l'habitat rupestre de Santa Elina, Mato Grosso (Brésil). Techne, Paris, n. 3, p. 91-97, 1996. 
